\title{
Demand for Law and the Security of Property Rights: The Case of Post-Soviet Russia
}

\author{
JORDAN GANS-MORSE Northwestern University
}

\begin{abstract}
Ttudies of property rights overwhelmingly focus on whether states expropriate or protect property, overlooking the crucial issue of whether private sector actors will use state institutions. By contrast, I argue that the "supply" of formal legal institutions often fails to ensure firms will rely on the state for property rights protection. Instead, firms frequently avoid formal legal institutions and turn to illegal strategies based on violence or corruption. Whether firms adopt legal strategies depends on: (1) firm-level practices and beliefs that impede the use of law, (2) the effectiveness of illegal strategies, and (3) coordination problems resulting from firms' expectations about each other's strategies. Drawing on interviews with firms, lawyers, and private security agencies, as well as an original survey of Russian enterprises, I illustrate how "demand-side" factors led to a surprising increase in Russian firms' reliance on formal legal institutions over the past two decades. The findings suggest that comprehensive understanding of property rights and the rule of law requires not only attention to state institutions' effectiveness, but also to private actors' strategies.
\end{abstract}

$\mathbf{R}$ ecognizing the importance of secure property rights for economic development, social scientists for decades have sought to explain why certain states expropriate property while others develop institutions that allow property rights to flourish (e.g., Acemoglu and Robinson 2006; North 1981; Olson 1993). Much less attention has been devoted to the question of the extent to which firms and other private sector actors will use state institutions, should rulers choose to provide them. ${ }^{1}$

That private sector actors will use state institutions cannot be taken for granted. Since Macaulay's (1963) seminal work, scholars widely have accepted that firms frequently turn to litigation or law enforcement officials only as a last resort, preferring instead to resolve conflicts on the basis of personal relationships and informal norms. Moreover, under certain conditions, firms employ strategies that are not merely informal, but rather outright illegal. For instance, unregistered

Jordan Gans-Morse is Assistant Professor, Department of Political Science, Northwestern University, 601 University Place, Evanston, IL 60208 (jordan.gans-morse@northwestern.edu).

The author thanks Neil Abrams, Karen Alter, Marc Berenson, Jose Cheibub, Georgy Egorov, M. Steven Fish, Timothy Frye, Scott Gehlbach, Anna Grzymala-Busse, Kathryn Hendley, Alisha Holland, Sarah Hummel, William Hurst, PJ Lamberson, Benjamin Lessing, Pauline Jones Luong, James Mahoney, Stanislav Markus, Israel Marques, Evgeniia Mikriukova, Stephen Nelson, Simeon Nichter, Robert Orttung, Andrew Roberts, Jason Seawright, David Szakonyi, Kateryna Vago, Steven Vogel, Jeffrey Winters, Matthew Winters, Andrei Yakovlev, Dong Zhang, and John Zysman. This research has received support from an NSF DDIG grant (SES-0921635), the Fulbright-Hays DDRA program, the SSRC Eurasia program, the American Bar Foundation, and the Kellogg School of Management Dispute Resolution Research Center.

Received: June 26, 2015; revised: May 24, 2016; accepted: July 19, 2016. First published online: February 20, 2017.

\footnotetext{
${ }^{1}$ A handful of economists have developed models of institutional demand analyzing private sector lobbying for or against the rule of law (Hoff and Stiglitz 2004; Polishchuk and Savvateev 2004; Sonin 2003), and there is a sizable literature on how firms secure property and contracts in the absence of effective state institutions (e.g., Greif 1993; Haber et al. 2003; Markus 2012; McMillan and Woodruff 1999). These studies offer valuable insights but do not address the question of why firms do or do not use formal legal institutions.
}

firms in Peru rely on "the protection that local bullies or mafias are willing to sell them" (de Soto 2003, 155), while in Indonesia some private security companies offer services that include "the intimidation of a client's business rivals" (Wilson 2010, 255). In addition to violence, firms frequently exploit corruption within the state. In China there is evidence that "entire [government] bureaus... support private firms in ways of varying legality" (Wank 2004, 113), while in Kyrgyzstan, according to one Bishkek-based journalist, "conflicts about property ... are impossible to resolve if you do not have contacts with the president or with high-ranking officials" (cited in Spector 2008, 163). In Russia following the Soviet Union's collapse, firms' use of violence and corruption became particularly extreme. In the mid-1990s two out of five enterprise managers reported facing physical coercion in the course of doing business (Radaev 1999, 36-40), while well into the 2000s law enforcement officials continued to intervene "informally as private enforcers" on behalf of firms engaged in business disputes (Volkov 2002, xii).

When do firms use violence and corruption, such as private protection rackets and illicit government connections, to protect property rights? And when do firms instead use formal legal institutions, such as courts and law enforcement agencies? The tempting answer would be that firms turn to law when state capacity is high and resort to illegal strategies when the state is weak. Indeed, to the extent that the prominent property rights studies cited above consider firms' use of state institutions, they assume that private actors' willingness to turn to the state depends primarily on formal institutions' effectiveness. By contrast, this article recognizes the state's important role in maintaining property security but also contends that state "supply" of institutions is a necessary but frequently insufficient condition for firms to rely on law. Instead, three factors other than state capacity often determine whether firms utilize violence and corruption, or whether firms employ legal strategies. These factors are (1) firm-level practices and beliefs that lead firms to avoid legal strategies (i.e., "demand-side" barriers), (2) the effectiveness of illegal strategies for securing property, and (3) 
coordination problems resulting from firms' expectations about other firms' willingness to use law. ${ }^{2}$

This article illustrates the importance of demandside factors for understanding firms' reliance on legal institutions through a detailed study of firm strategies for securing property in Russia over the two decades following the Soviet Union's collapse. The case of postSoviet Russia is noteworthy for two reasons. First, one might expect that once economies become mired in violence or corruption, these circumstances persist indefinitely, or at best evolve toward legality over many years. And indeed, disproportionate attention to high-profile clashes involving owners of Russia's largest conglomerates, frequently referred to as "oligarchs," has perpetuated Russian capitalism's lawless image (see, e.g., Barnes 2003; Hoffman 2002). But analysis of Russia's understudied nonoligarchic firms, many of which are small or medium enterprises, reveals that these firms' strategies have evolved dramatically. Between 1994 and 2010, the number of annual court cases initiated by Russian firms quintupled, increasing from around 200,000 to over one million (VAS 2011). More broadly, based on in-depth interviews with firms, lawyers, and private security agencies, as well as an original survey of enterprises from eight cities, I demonstrate that many Russian firms replaced violence and corruption with reliance on formal legal institutions beginning in the late 1990s.

Second, given Russia's long history of state-led development, one might expect that increasing use of legal strategies can be attributed to changes in the effectiveness of state institutions. However, a statecentric explanation can at best partially account for Russian firms' evolving strategies: During the period in which firms increasingly utilized law, the effectiveness of Russia's formal legal institutions improved only modestly, and in many ways the Russian state became more corrupt and predatory. By contrast, analysis of demand-side factors offers significant insights into Russian firms' adoption of legal strategies. In particular, firms' partial emergence from the shadow economy reduced a major demand-side barrier to the use of law by mitigating firms' concerns that turning to legal institutions might expose illicit practices related to tax evasion. Similarly, the consolidation of ownership in privatized firms reduced owners' readiness to incur risks associated with violence and corruption, undermining illegal strategies' effectiveness. In turn, declining demand-side barriers and effectiveness of illegal strategies altered firms' expectations about each other's strategies, helping overcome coordination problems that had impeded willingness to use law.

Beyond offering insights into firm strategies and their evolution in post-Soviet Russia, the broader contribution of this article is to shed light on why institutional reforms implemented without consideration of

\footnotetext{
2 These arguments build on Pistor (1996) and Hendley (1997; 1999), but whereas the primary concern of these earlier works was to understand why firms in countries such as Russia were not using formal legal institutions, my focus is on conditions under which firms do turn to legal strategies.
}

firms' and citizens' everyday practices frequently fail. As prominent legal scholars have emphasized, firms' use of violence and corruption undermines formal institutions, whereas firms' use of courts and law enforcement reinforces formal institutions' effectiveness and relevance (Hendley 1997; Pistor 1996). It follows that comprehensive understanding of the rule of law and the security of property requires more than attention to top-down institutional reforms. Instead, the demand-side approach to property security advocated here provides a novel perspective on the development of state capacity, suggesting, along the lines of Migdal's (2001) "state-in-society" approach, that effective statebuilding depends not only on rulers' policies but also on societal actors' strategies.

The remainder of this article is divided into four sections. The following section provides an overview of Russian firms' evolving strategies for securing property throughout the post-Soviet period. The second section then offers a theory of institutional demand and formalizes the argument with a simple model. The third section illustrates the theory using qualitative and quantitative evidence drawn from the Russian case. Finally, the concluding section considers the argument's generalizability and emphasizes broader implications of a demand-side approach to property security.

\section{EVOLVING PROPERTY SECURITY STRATEGIES IN POST-SOVIET RUSSIA}

This article examines variation over time in Russian firms' property security strategies: firms' efforts to resolve conflicts related to acquiring assets, protecting property, and enforcing contracts. The concept of property security employed here is broader than the concept of property rights, which frequently are defined as the rights to use, derive income from, and transfer an asset to another owner (Barzel 1997, 3). Throughout history, force has been wielded to accumulate and protect claims to property. By contrast, the concept of "rights" presupposes the existence of the modern state, which publicly codifies the law, identifies citizens' privileges and obligations, and establishes the distinction between legitimate and illegitimate ownership (Winters 2011, 7). In modern societies, relying on formal legal institutions to enforce property rights is one possible strategy for securing property. But as noted above, firms in many societies also continue to employ violence and corruption to protect property claims without reference to law. Property security therefore encompasses strategies both for protecting property claims and for enforcing property rights. ${ }^{3}$

Drawing on 90 interviews conducted throughout 2009 with firms, lawyers, and private security agencies,

\footnotetext{
${ }^{3}$ To be clear, this article does not evaluate arguments about the value of property rights per se, but rather focuses on how firms secure property, with a particular emphasis on whether firms use formal legal institutions. Nevertheless, firms' confidence in legal institutions is strongly correlated with important indicators of property rights' value, such as firms' rates of investment (see, e.g., Frye 2004; Johnson et al. 2002).
} 
as well as a survey of 301 firms from eight Russian cities carried out in 2010, this section details Russian firms' reduced reliance on illegal and increased use of legal property security strategies over the past two decades. ${ }^{4}$ In the late 1980 s and early 1990 s, violence played an extraordinary role in Russian firms' economic relations. Criminal protection rackets originally formed to extort kiosks in open-air markets but soon evolved into more complex operations. Criminal gangs offered entrepreneurs - particularly smaller businesses - services including protection against other extortionists, enforcement of contracts, collection of debt, and intelligence gathering on prospective business partners (Volkov 2002). Along with criminal rackets, private security agencies multiplied rapidly, while larger firms created internal security services, described by the journalist David Hoffman (1997) as "private armies of security agents, bodyguards and commercial spies." By 1993, there were already approximately 5,000 registered private security agencies; by the late 2000 s, this figure was estimated to be 30,000 (GansMorse 2012, 267; Volkov 2002, 138). ${ }^{5}$

From the mid-1990s onward, however, violence in the Russian business world declined. Matveeva (2007, 86) analyzed business conflicts in Russia's Central Federal District between 1997 and 2005 and recorded a significant drop in annual businesspeople murdered, from 213 to 33. Businesspeople corroborate this decline in violence. A survey conducted by Radaev (1999) of 221 firms across 21 Russian regions in 1997 revealed that approximately two out of five respondents reported personally experiencing violent extortion or threats of physical coercion "sometimes" or "often." By contrast, in my 2010 survey of 301 firms from eight Russian cities, less than five percent of respondents reported a similar frequency of threats or coercion. Surveys also provide evidence of criminal rackets' decline. Frye and Zhuravskaya (2000) found in a 1996 survey of 230 small retail shops in Moscow, Ulyanovsk, and Smolensk that over 40 percent of respondents reported having contact with criminal groups in the previous six months. ${ }^{6} \mathrm{My}$ 2010 survey found that less than 8 percent of 105 small businesses in the sample (and less than 4 percent of the 301 firms in the overall sample) reported contact with rackets at any point in the previous three years. ${ }^{7}$

\footnotetext{
${ }^{4}$ The survey was conducted in Moscow, St. Petersburg, Ekaterinburg, Nizhniy Novgorod, Samara, Novosibirsk, Rostov-on-Don, and Kazan. For additional information, see Section 2 of the Online Appendix.

${ }^{5}$ Although some private security agencies and internal security services operated legally, many others did not, as noted by Volkov (2002, 143): "The use of force and intimidation to recover debts and settle disputes among businessmen is one of the major activities of criminal groups. Many PPCs [private protection companies] are also involved in this business, using purely criminal methods."

${ }^{6}$ Other survey studies documenting the extensiveness of protection payments include Johnson et al. (2002) and Radaev (1999). For a dissenting view suggesting that criminal rackets were less pervasive, at least among larger firms, see Hendley et al. (2000).

7 Comparison of nonpanel surveys across time periods warrants caution (see Frye 2010, 85-6), but the magnitude of the shifts - often 30 or more percentage points - as well as the fact that nonsurvey data point to similar conclusions indicate that claims concerning the decline in violence are well founded.
}

The extent of criminal protection rackets' decline is best summarized by the cofounder of a prominent Moscow private security agency. In the early 1990s, he explained, the majority of his firm's work involved helping clients deal with rackets. By 1995, a noticeable shift was occurring: “.... criminal groups were disappearing to such an extent that they were becoming simply something exotic. If a client came to us and said that some thugs from the street had tried to extort him, well, this was for us something exciting. [It gave us a] sort of nostalgia for the old days" (Security Firm 5 , interview, 18 September 2009). The shift away from violence is also apparent in the private security sector. By the late 2000s, security agencies differed little from their Western counterparts, with experts estimating that provision of basic physical security of buildings, cargo, and business executives accounted for 70 percent of the sector's revenues, the rest consisting of information security, legal services, and installment of cameras and alarms. ${ }^{8}$

As reliance on violence waned, Russian firms turned to two types of strategies for securing property. On the one hand, they increasingly utilized strategies relying on the corrupt appropriation of state resources, such as protection rackets offered by law enforcement officials. At the same time, however, firms began to utilize formal legal institutions in earnest.

Law enforcement rackets offered many of the services previously provided by criminal organizations, including debt collection, contract enforcement, and adjudication of disputes. By the early 2000s, observers estimated that criminal rackets maintained control of around 10-20 percent of the private security market, while law enforcement protection services divided up the remaining clients (Khodorych 2002; Volkov 2002, 169-70). One journalist summarized the situation as follows: "By the end of the 1990s, the majority of entrepreneurs capable of making money were 'voluntarily' providing support to the law enforcement authorities. It could be said that the country had been divided into zones of 'police patronage' [militseiskoy otvetstvennosti]" (Sborov 2003). Many of these practices have persisted. In the 2010 survey I conducted, approximately 20 and 17 percent of firms reported using bureaucrats and law enforcement agencies, respectively, in an "unofficial capacity" to address a security issue in the previous three years, while nearly 14 percent of respondents admitted relying on "informal connections" in the commercial courts.

Yet a focus on corruption's persistence and subversive uses of formal legal institutions overlooks broader changes in Russian firms' strategies over the last two decades. From a low point of around 200,000 in 1994, the number of cases initiated by firms in Russia's commercial courts approximately quintupled, to over a million by 2010 (VAS 2011). ${ }^{9}$ While rising caseloads

\footnotetext{
8 Aleksandr Ivanchenko, Director of Russian Security Industry Association. Interviewed on June 8, 2009.

${ }^{9}$ Russia's commercial courts (arbitrazhnye sudy) are specialized courts within the state judicial system that hear civil disputes among firms and civil or administrative cases between firms and the state.
} 
can reflect increased legal violations rather than increased willingness to use law, between 2000 and 2007 the number of violations reported by firms in fact $d e$ clined (Yakovlev 2008, 231). In further support of a genuine strategy shift, 54 percent of respondents in the 2010 survey I conducted reported being more willing to turn to courts as compared to 10 years ago. Only 6 percent reported being less willing. (Thirty-three percent reported their willingness remained unchanged and 7 percent answered "don't know.") Overall, numerous surveys conducted since the late 1990s have documented firms' extensive use of legal institutions, with about one-third of smaller and two-thirds of larger firms having utilized the commercial courts (e.g., Hendley et al. 2000; Yakovlev 2008; Yakovlev et al. 2004).

Litigation rates reflect, of course, only a fraction of firms' reliance on legal strategies. For every dispute in court, countless others are negotiated in "the shadow of the law," where the threat of litigation shapes negotiations (Mnookin and Kornhauser 1978). But there is broader evidence that law plays an increasingly important role in Russian business. One indicator is the growing population of lawyers, which more than doubled between 1996 and 2010 (Gans-Morse 2012,274-5). Lawyers themselves, moreover, see significant changes in their profession's role. As one of Russia's top tax lawyers recalled, today there is booming demand for his services, whereas in the 1990s his " ... main problem was not winning, but convincing businesspeople that it is worth going to court" (Lawyer 21, interview, 5 November 2009). Nor is firms' increasing reliance on formal legal institutions limited to Moscow, as indicated by the observation of a lawyer from the Siberian town of Barnaul that "... people more or less have come to resolve disputes in a civilized way, by going to court." According to this lawyer, courts are so packed with litigants that "... to move through the corridors of a courthouse is now impossible" (Lawyer 22, interview, 30 September 2009).

The most striking evidence of law's role in contemporary Russia is how firms evaluate their use of lawyers and courts relative to other property security strategies. As seen in Table 1, when respondents were asked to rank on a 1 to 7 scale how likely a firm like theirs would be to utilize various strategies to resolve a property dispute (with 7 meaning "very likely" and 1 meaning "very unlikely"), the highest ranking strategies were the use of lawyers to resolve the conflict out of court (average ranking 6.0) and filing a claim in the commercial courts (5.7). By contrast, the average rankings for the likelihood of turning to a private security firm or criminal racket were 2.3 and 1.9 , respectively, while the use of strategies relying on corruption fell somewhere in between. A similar question examining preferred strategies for collecting a debt produced nearly identical results.

Before considering explanations for Russian firms' evolving strategies, several issues warrant discussion.

Criminal cases are heard separately in the courts of general jurisdiction (sudy obshchey yurisdiktsii).
First, while social desirability bias or respondents' imperfect recall are inherent concerns when researching sensitive topics, the fact that quantitative survey data, qualitative interview data, and objective data such as caseloads all point to similar conclusions should in part mitigate such concerns. ${ }^{10}$ Moreover, the magnitude of trends in question is noteworthy. For instance, approximately 40 percent of firms openly reported contact with criminal rackets in the 1990 s while fewer than 10 percent report contact in recent surveys. ${ }^{11}$ There is no evidence that respondents' trustworthiness changed dramatically enough over time to account for such sizable shifts. Meanwhile, it should not be assumed that businesspeople have an incentive to overreport their use of the legal system. To the contrary, Macaulay's (1963) classic study suggests that litigation against business partners breaches social norms, which might encourage respondents to understate reliance on law.

A second possible concern is that firms' use of legal institutions primarily reflects increased bribery and exploitation of judicial corruption rather than increased reliance on law. But scholars such as Hendley (2006, 351) have found that although "cases that attract the interest of those in power can be manipulated to serve their interests," such concerns do not apply to the bulk of disputes: "mundane cases are handled in accordance with the prevailing law." Similarly, the partner of a Moscow law firm explained that "Connections are probably needed if the case is high-profile, big or political, or if the opponent is a large company. But for middle-sized cases they are not necessary .... and the majority of cases are rather small...." (Lawyer 6, interview, 6 March 2009). Finally, while there has been a general trend toward legal strategies over time, it is important to recognize that this trend occurred unevenly across different types of firms. Indeed, cross-firm variation should be expected according to the demand-side approach developed below, for key explanatory factors such tax compliance or ownership consolidation themselves occur unevenly across firm types.

In summary, whereas firms extensively utilized violence in the early-to-mid 1990s, such strategies have become a rarity. And while reliance on protection rackets offered by government officials and other corrupt strategies persists, firms' widespread use of legal institutions cannot be attributed to exploitation of a corrupt judicial system. Rather, Russian firms have come to rely extensively on law and lawyers to protect property and enforce contracts.

\section{EXPLAINING DEMAND FOR LAW: A THEORY AND MODEL}

What accounts for the evolution of firms' property security strategies in Russia and beyond? The focus on rulers and states in Acemoglu and Robinson (2006),

\footnotetext{
${ }^{10}$ See Section 3 of the Online Appendix for additional discussion of data collection concerns.

11 These figures refer to Frye and Zhuravskaya's 1996 survey and to my 2010 survey cited on the previous page.
} 


\section{TABLE 1. Russian Firms' Preferred Property Security Strategies}

Respondents were asked the following questions:

Debt Dispute: Let's say that another company owes your firm a significant sum of money for products purchased or services rendered and has not made the payment, even though the agreed upon deadline has passed. To recover the money owed, how likely would a firm like yours be to use each of the following?

Property Dispute: Let's say that a competitor is trying to gain control of some significant physical asset owned by your firm (e.g., office space or a factory). To defend its assets, how likely would a firm like yours be to do each of the following?

Average responses on a scale of 1 to 7 , where 1 is "very unlikely" and 7 is "very likely"

\section{Legal Strategies}

Rely on lawyers to resolve the dispute out of court

Turn to the commercial courts

Seek the help of law enforcement officials acting in their formal capacity

Seek the help of government bureaucrats acting in their formal capacity

\section{Illegal Strategies (corruption)}

Turn to the commercial courts, using informal connections

Seek the help of law enforcement officials acting in an informal capacity

Seek the help of government bureaucrats acting in an informal capacity

$\begin{array}{cc}\text { Debt } & \text { Property } \\ 6.31 & 6.04 \\ (301,0.07) & (297,0.09) \\ 5.86 & 5.69 \\ (292,0.09) & (293,0.10) \\ 4.83 & 5.18 \\ (298,0.13) & (295,0.12) \\ 3.99 & 4.57 \\ (294,0.13) & (290,0.12)\end{array}$

\section{Illegal Strategies (violence)}

Rely on an internal security service

Seek the help of a private security agency

Seek the help of criminal or mafia groups

4.32

$(268,0.14)$

3.78

$(280,0.13)$

3.63

$(281,0.13)$

Note: The number of observations and standard errors are in parentheses.

North (1981), Olson (1993), and other prominent property rights studies, directs attention to rising state capacity as a probable explanation for firms' increased use of law or decreased use of violence and corruption. This article, by contrast, emphasizes the key role of firms' demand for institutions. Before developing my argument, the following section highlights why statecentric approaches frequently provide only a partial explanation for why firms adopt legal strategies.

\section{Supply-Side Approaches}

It is tempting to assume that the effectiveness of formal legal institutions explains whether firms are willing to use legal strategies. ${ }^{12}$ And to be sure, where state legal capacity is altogether lacking, firms are unlikely to rely on law. ${ }^{13}$ However, the inverse is not necessarily true: supplying effective institutions does not guar-

\footnotetext{
12 I define formal legal institutions as both the formal rules (e.g., laws and government decrees) that shape economic relations and also the state organizations charged with enforcing these rules. Although courts may be the most obvious institution in this category, law enforcement and specialized regulatory agencies also play essential roles in securing property.

${ }^{13}$ For example, McMillan and Woodruff $(1999,652-3)$ found that 90 percent of Vietnamese firms they surveyed believe "courts are of no use ... in enforcing contracts or resolving disputes," and consequently these firms not only avoid courts but more broadly "contract without the shadow of the law."
}

antee firms will use them. For instance, Pistor et al. $(1999,17)$ emphasize that courts in fast-growing East Asian countries-countries renowned for high state capacity - for decades figured prominently in criminal cases but "played a less important role in settling commercial disputes." Furthermore, firms not only eschew legal strategies in some societies with relatively effective legal institutions, but firms also turn to law in other societies where legal institutions' weaknesses are wellknown. For example, Whiting $(2010,183)$ documents a 20-fold increase between 1983 and 2001 in economic disputes heard by China's courts despite the fact that "Courts in the PRC are subordinate to the party, lack competent judges, and have weak enforcement powers." Thus, without denying the importance of state legal capacity, existing evidence indicates that the correlation between legal institutions' effectiveness and firm strategies is far from determinative.

Beyond the effectiveness of formal legal institutions, state capacity might be expected to influence firm strategies in other ways. States capable of providing economic growth and political stability arguably create a business environment conducive to legal strategies. Yet prominent counterexamples raise questions about the explanatory power of such macrostructural arguments. Milhaupt and West (2000) find that despite decades of growth and stability, Japanese firms have relied persistently and extensively on criminal rackets for services ranging from debt collection to resolution 
of shareholder conflicts. Meanwhile, Japanese firms historically have shown an even lower propensity to utilize legal strategies than their counterparts in lesser developed East Asian countries such as South Korea and Taiwan (Pistor et al. 1999, 215). Macrostructural arguments also leave important questions unanswered. For example, they fail to illuminate the heterogeneity in strategies across different types of firms noted in the preceding section. For these and related reasons, later sections of this article make clear that neither increased effectiveness of legal institutions, nor improved state capacity more broadly, adequately explain Russian firms' evolving property security strategies.

Overall, supply-side explanations offer valuable insights yet remain incomplete. They struggle to explain cases in which state legal capacity is relatively high yet firms circumvent formal legal institutions, as well as cases in which shifts in firm strategies occur in the absence of heightened state legal capacity. They also fall short in explaining variation in strategies across different types of firms. A key contribution of this article is thus to integrate existing supply-side approaches with a complementary demand-side approach, thereby offering a framework for more comprehensive understanding of property security.

\section{A Demand-Side Approach}

The shortcomings of supply-side approaches make clear that effective state institutions are necessary but frequently insufficient to induce firms' use of legal institutions. Instead, firms' willingness to adopt legal strategies depends on three factors unrelated to state "supply" of effective institutions: (1) the prevalence of demand-side barriers to the use of formal institutions, (2) the effectiveness of illegal strategies; and (3) the extent of coordination problems resulting from expectations about other firms' strategies. This section elaborates on each of these factors; the following section formalizes the argument with a simple model.

Demand-side barriers are practices and beliefs that inhibit firms' willingness to use formal legal institutions. They can result from cultural factors, which according to some scholars account for low reliance on legal institutions in many East Asian countries (see the discussion in Ginsburg and Hoetker 2006, 33-4). But perhaps the most prominent demand-side barrier in many countries, and the barrier on which I focus below, pertains to firms' operations in the unofficial economy. As Hay and Shleifer $(1998,399)$ explain, firms in the shadow economy are nearly always "in violation of some tax, customs, foreign-exchange, or regulatory rules" and consequently cannot "use the official legal system for fear of exposure." While it has been rare for Russian firms to operate without registration (i.e., fully in the informal economy), throughout the 1990s firms frequently hid revenue from the tax authorities. Consequently, a key factor contributing to firms' increasing reliance on legal strategies has been improved levels of tax compliance.
Second, as with any competing set of services, firms' willingness to use formal legal institutions depends on the effectiveness of illegal strategies, which depends in turn on at least two factors: transaction costs and the risk of sanctions. There is a rich body of literature analyzing transaction costs and the relative effectiveness of alternatives to formal legal institutions (e.g., Macaulay 1963; Williamson 1985). But what sets the use of illegal strategies apart from the use of informal strategies (i.e., strategies that do not directly rely on formal legal institutions yet do not inherently violate the law) is the risk of sanctions, including physical harm, criminal prosecution, or the loss of funding from investors wary of a firm's unsavory reputation. An increase in state legal capacity is one possible source of such sanctions. But in the Russian case a number of demand-side factors have affected the risk of using illegal strategies. In later sections I analyze the impact of evolving ownership structures on Russian owners' willingness to employ violence and corruption. Whereas dispersed ownership and minimal minority shareholder protections created incentives for owners in the 1990s to use any means possible to acquire assets in ongoing ownership battles, the ownership consolidation that occurred by the 2000 s changed owners' calculus of risk. Seeking longer-term profits through productive investments, owners recognized that illegal strategies could undermine firms' reputations and destabilize the overall business climate. As a result, illegal strategies' effectiveness relative to legal strategies declined.

Third, because of the unique nature of law, coordination problems affect property security strategies. Specifically, law matters most when a sufficient proportion of a society perceives that other members of society also believe law matters and act accordingly (Hendley 1999, 92-3). Consequently, firms' concerns about other firms' persistent use of violence and corruption hinder the adoption of legal strategies, and a shift toward law requires a shift in firms' expectations. These coordination problems create a dynamic resembling the tipping point models scholars have used to analyze revolutions, neighborhood segregation, and the adoption of national languages (Kuran 1989; Laitin 1998; Schelling 1971). As in such models, the value to using legal strategies remains lower than the value to using illegal strategies until a critical mass of firms comes to use legal strategies, at which point the economy "tips" toward a new equilibrium in which the value of using legal strategies surpasses the value of using illegal strategies. One of the key implications of such dynamics is that the vicious and virtuous cycles resulting from firms' expectations about each other amplify the effects of other trends. When demand-side barriers or illegal strategies' effectiveness declines, these changes directly lead some firms to use legal strategies more extensively. If the proportion of firms initially adopting legal strategies is sufficiently large to "tip" an economy toward a more lawful equilibrium, then the initial reduction in demand-side barriers will also indirectly affect firm strategies, as firms' expectations that other firms are increasingly turning to law becomes 
an independent factor encouraging adoption of legal strategies. ${ }^{14}$

As a heuristic device for the empirical analyses that follow, the model below formalizes the theory discussed thus far. It elucidates (1) why state legal capacity is a necessary but frequently insufficient condition for firms to use legal strategies, (2) why firms frequently adopt legal strategies even without improvements in legal capacity, due to declining demand-side barriers or the decreasing effectiveness of illegal strategies.

\section{Formalizing the Argument}

Consider a game in which a conflict arises between two firms drawn randomly from a large population of identical firms over an asset with value $V$. Each firm $i$ has a pure strategy space $s_{i}=\{L, I\}$, where $L$ represents legal and $I$ represents illegal strategies. An endogenous proportion $\lambda$ of firms rely on legal strategies, while a proportion $1-\lambda$ rely on illegal strategies. When the conflict begins, the two firms choose their strategies simultaneously, representing firms' inability to observe the preferred strategies of other individual firms. After both firms choose a strategy, payoffs are realized and the game ends. The payoffs are as follows:

Legal vs. legal strategies The loser receives nothing while the winner receives $(\alpha-\gamma) V$, where $\alpha \in(0,1)$ is a measure of the effectiveness of formal legal institutions and $\gamma \in(0, \alpha)$ is a measure of demand-side barriers. Because identical firms using the same strategy have an equal chance of winning, the expected payoff for either firm is $(\alpha-\gamma) \frac{V}{2}$.

Illegal vs. illegal strategies The loser receives nothing while the winner receives $\beta V$, where $\beta \in(0,1)$ is a measure of illegal strategies' effectiveness. The state detects illegal strategies with probability $q$ and confiscates all assets, a payoff of 0 . Because identical firms using the same strategy have an equal chance of winning, the expected payoff for either firm is $(1-q) \beta \frac{V}{2}$.

Legal vs. illegal strategies The firm using the illegal strategy wins the conflict and acquires the asset of value $V$, but with probability $q$ the state detects the illegal activity, confiscates the assets, and returns them to the lawful firm. Accordingly, the expected payoff for the firm using a legal strategy is $q(\alpha-\gamma) V$, where $\alpha$ again represents the effectiveness of the legal institutions used for restitution and $\gamma$ captures demand-side barriers. Correspondingly, the expected payoff for the firm using an illegal strategy is $(1-q) \beta V .^{15}$

\footnotetext{
${ }^{14}$ Another potential explanatory factor that complements the demand-side variables introduced here pertains to experiential learning. If market-supporting legal institutions are conceptualized as a new technology, then average costs of employing legal strategies might be expected to decrease over time through a process of "learning-by-doing" (see, e.g., Arrow 1962). However, regression analyses presented in Section 6 of the Online Appendix do not produce robust evidence in favor of an experiential learning hypothesis. All regressions in the article nevertheless control for key variables related to the learning hypothesis, including firm age and previous litigation experience.

15 Assuming illegal beat legal strategies simplifies analysis but does not qualitatively change results. I make one additional technical
}

A Nash equilibrium (NE) in this game will be a profile of strategies such that each firm's strategy is a best response to all other firms' strategies. More formally, a $\mathrm{NE}$ is a strategy profile $\left(s_{i}^{*}, s_{-i}^{*}\right)$ for all firms $i \in \mathcal{I}$ such that $s_{i}^{*} \in B R_{i}\left(s_{-i}^{*}\right)$.

To examine the effects of state legal capacity on firm strategies, first consider an economy in which legal institutions $(\alpha)$ are ineffective to such a degree that a firm's expected payoff to using illegal strategies is greater than the payoff to using legal strategies regardless of other firms' strategies. In this low-capacity economy, the unique NE is for all firms to utilize illegal strategies. Consequently, a necessary condition for firms' use of legal strategies is that legal capacity must be high enough that the equilibrium in which all firms use illegal strategies is no longer unique. Now consider an economy in which formal legal institutions are effective enough that a firm's expected payoff to using legal strategies is at least as great as the payoff to using illegal strategies, but only if a sufficient number of other firms also employ legal strategies. In such intermediate-capacity economies, multiple equilibria exist, including equilibria in which some or all firms use legal strategies (as discussed below) but also an equilibrium in which all firms use illegal strategies. In other words, an intermediate level of legal capacity is insufficient to guarantee firms' use of legal strategies. The following proposition formalizes these intuitions:

Proposition 1: Let $\underline{\alpha}=2 \beta(1-q)+\gamma$ and $\bar{\alpha}=\frac{\beta}{2 q}(1-$ q) $+\gamma \cdot$ Then $^{16}$

1. For any $\alpha<\underline{\alpha}$, the unique $N E$ for the game is $s_{i}^{*}=I$ for all firms $i \in \mathcal{I}$.

2. For any $\alpha \in[\underline{\alpha}, \bar{\alpha})$, there exists a NE in which $s_{i}^{*}=I$ for all firms $i \in \mathcal{I}$.

Proposition 1 states that $\alpha \geq \underline{\alpha}$ is a necessary but insufficient condition for the use of legal strategies. Consequently, state legal capacity plays a central role in inducing firms to rely on law, but explanations relying on state capacity alone remain incomplete.

Complete explanations require further consideration of demand-side factors, particularly in intermediate-capacity states (i.e., in states where $\alpha \in$ $[\alpha, \bar{\alpha})) .{ }^{17}$ For this region of the parameter space, illegal strategies yield higher payoffs than legal strategies when all firms use illegal strategies (i.e., when $\lambda=0$ ) and legal strategies yield higher payoffs than illegal

assumption that $q<\frac{1}{4}$. This assumption rules out regions of the parameter space that result in a game of chicken, in which illegal strategies are a best response to legal strategies and vice versa, for it is difficult to conceive of real-world scenarios represented by such a game.

${ }^{16}$ Formal proofs for all propositions are included in Section 4 of the Online Appendix.

${ }^{17}$ A sufficient condition for a unique NE in which all firms use legal strategies is $\alpha \geq \bar{\alpha}$. Substantively, this corresponds to high-capacity states such as the advanced industrialized countries. However, this article's focus is on intermediate-capacity states in which legal capacity is sufficient to make legal strategies viable but insufficient to ensure a unique lawful equilibrium. 
strategies when all firms use legal strategies (i.e., when $\lambda=1)$. Consequently, when all firms use the same strategy, no firm can increase its expected payoffs by adopting an alternative strategy. Meanwhile, a third equilibrium exists in which $\lambda=\lambda^{*}$, where $\lambda^{*}$ is the proportion of firms using legal strategies such that the marginal firm is indifferent between legal and illegal strategies. Although such an equilibrium is "unstable," in the sense that a small perturbation of parameter values leads all firms to adopt either legal or illegal strategies, no firm has an incentive to alter its strategy given the distribution of strategies in the economy.

The proportion of firms using legal strategies, $\lambda^{*}$, represents a tipping point. To analyze demand-side factors' impact, the marginal firm's indifference condition can be written

$$
\begin{aligned}
\lambda^{*} & {\left[\frac{(\alpha-\gamma)}{2}-(1-q) \beta\right] } \\
& =\left(1-\lambda^{*}\right)\left[(1-q) \frac{\beta}{2}-q(\alpha-\gamma)\right] .
\end{aligned}
$$

When the left-hand side of Equation (1) increases, an economy "tips" toward an equilibrium in which all firms use legal strategies; when the righthand side increases, the opposite occurs. The equation offers insights into parameter shifts that make tips more likely. All else equal, Equation (1) indicates that it becomes easier to a tip an economy toward a lawful equilibrium as state legal capacity $(\alpha)$ increases. But in many developing countries, legal reforms are politically or technically infeasible. Fortunately, Equation (1) also makes clear that even if legal capacity remains stagnant or marginally deteriorates, sufficiently large declines in demand-side barriers $(\gamma)$ or the effectiveness of illegal strategies $(\beta)$ for a sufficiently large group of firms can facilitate a tip toward a lawful equilibrium. The theory's second key proposition formalizes these intuitions:

Proposition 2: Given $q, \beta$ and $\gamma$, let $\alpha \in[\underline{\alpha}, \bar{\alpha})$, where $\underline{\alpha}$ and $\bar{\alpha}$ are as defined in Proposition 1. Suppose initially that $\lambda=0$. Then

1. For any $\hat{\alpha} \in[\underline{\alpha}, \bar{\alpha}]$ and $\hat{\gamma} \leq \gamma$, there exists a $\hat{\beta}$ such that if $\beta$ declines to $\hat{\beta}$ for a portion of firms $\omega \geq \lambda^{*}$, then $\lambda=\lambda^{*}$ or $\lambda=1$ will be an equilibrium.

2. For any $\hat{\alpha} \in[\underline{\alpha}, \bar{\alpha}]$ and $\hat{\beta} \leq \beta$, there exists $a \hat{\gamma}$ such that if $\gamma$ declines to $\hat{\gamma}$ for a portion of firms $\omega \geq \lambda^{*}$, then $\lambda=\lambda^{*}$ or $\lambda=1$ will be an equilibrium. ${ }^{18}$

Proposition 2 states that given a necessary level of state legal capacity $\alpha \geq \underline{\alpha}$, falling demand-side barriers and/or declining effectiveness of illegal strategies can

${ }^{18}$ Part 2 requires the assumption $\gamma>\left(\frac{1}{2 q}-2\right)(1-q) \beta$. Substantively, this ensures that demand-side barriers $(\gamma)$ play a sufficiently large role in firms' initial reluctance to use legal strategies, such that a reduction in barriers can induce a strategy shift even holding illegal strategies' effectiveness $(\beta)$ constant. be sufficient conditions for firms to use legal strategies even if legal capacity is unchanged or decreasing. Consequently, demand-side factors frequently are determinative of firm strategies.

The simple model reveals the logic underlying the theory presented above. It elucidates (1) why state legal capacity is a necessary but frequently insufficient condition for firms to use legal strategies, and (2) why firms frequently adopt legal strategies even without heightened legal capacity. The model furthermore demonstrates how reducing demand-side barriers or illegal strategies' effectiveness has both a direct effect on firm strategies as well as an indirect effect as other firms adapt to the initial wave of strategy shifts. The following section examines these points in greater detail through analysis of the Russian case.

\section{SUPPLY AND DEMAND FOR LAW IN POST-SOVIET RUSSIA}

Post-Soviet Russia illustrates the theory's two main propositions. In accordance with Proposition 1, the Russian case makes evident how effective legal institutions are necessary but often insufficient to induce firms' use of law. In accordance with Proposition 2, the Russian case makes evident conditions under which demand-side factors determine firm strategies. Even when improvements in state legal capacity are modest, shifts in demand-side barriers, the effectiveness of illegal strategies, and expectations about other firms' strategies can induce firms to turn from violence and corruption toward law.

The current section first examines the role of state capacity in the Russian case. It then analyzes the impact on firm strategies of reduced demand-side barriers resulting from improved tax compliance, declining effectiveness of illegal strategies resulting from changes in privatized firms' ownership structures, and the mitigation of coordination problems resulting from firms' expectations about each other's willingness to adopt legal strategies.

\section{The Role of State Capacity}

The key tenet of Proposition 1-that rising effectiveness of formal legal institutions frequently is insufficient to induce firms' use of law-became rapidly apparent in post-Soviet Russia. During the chaos following the Soviet Union's collapse, formal institutions were in such disarray that firms often had few choices but to rely on corrupt state officials or violence supplied by private actors. Yet by the mid-1990s, significant institutional development had occurred, including new legislation on joint-stock companies, securities markets, and bankruptcy; a new Civil Code; and the formation of a new system of commercial courts. Surveying Russia's legal institutions, Hendley $(1999,90)$ concluded that "Comparing snapshots of the legal landscape in 1985 and 1998 would make immediately apparent the fundamental and far-reaching nature of recent reforms." However, she also emphasized how legal reformers' 
expectations that increased effectiveness of legal institutions would be followed by increased private sector reliance on law remained unfulfilled: "Although this connection between supply of and demand for law may have seemed self-evident, it has proven elusive in practice" (Hendley 1999, 89). Pistor $(1996,87)$ came to similar conclusions, noting that "In Russia, the early institutional changes aimed at providing a court system for handling commercial disputes have so far proved to be largely ineffective. The main reasons for this appear to lie less in the inefficiency of the system than in the lack of demand for the services that it offers." In short, a handful of legal scholars clearly recognized that heightened state legal capacity in the Russian case was insufficient to induce the use of legal institutions.

Often overlooked, however, is what came next. In line with the key tenets of Proposition 2-that firms often may increase their reliance on law even without heightened state legal capacity-firms turned to legal strategies throughout the late 1990s and 2000s despite significant reservations about the effectiveness of Russia's formal legal institutions. Indeed, Russian firms continued to adopt legal strategies throughout the 2000s despite rising corruption and predation by state officials.

Vladimir Putin came to power, first as Prime Minister in 1999 and then as President in 2000, with a mandate to rebuild the Russian state, which had reached the brink of financial collapse (Hill and Gaddy 2013, chap. 3). As Putin recentralized power, state revenues, aided by economic growth and skyrocketing oil prices, climbed steadily. Law enforcement, courts, and regulatory agencies began to reestablish a role in enforcing the rules governing Russia's economy. The probability that strategies based on violence or corruption would result in sanctions rose, and strategies relying on legal institutions became a potentially viable option. Yet these improvements should not be overstated. As Taylor $(2011,111)$ notes:

The achievements of [Putin's] state-building project were modest and partial, with the greatest gains in capacity taking place in rebuilding a regime of repression.... Much less progress was made in coping with ...core, routine tasks.... Repressing opposition figures and "bad" oligarchs certainly came much more naturally to Russian law enforcement officials than establishing a stable private property rights regime.

Buttressing this perspective is Russia's consistent rankings in the bottom quartile of international rankings such as the World Bank's Rule of Law Index throughout the 2000s. ${ }^{19}$

That firms perceived minimal improvements in Russian legal institutions' effectiveness can be seen in Figure 1, which shows firms' assessments of the court

\footnotetext{
${ }^{19}$ See World Governance Indicators "Country Data Report for Russia" at www.govindicators.org. Similarly, reversal rates of lower courts' decisions - a common measure of judicial quality (e.g., Posner 2000; Shvets 2012) - remained steady or increased from the late 1990s onward, with the exception of a brief decline in 2004 and 2005 (VAS, Osnovye pokazateli arbitrazhnykh sudov $R F$, various years).
}

system, drawing on data from the World Bank-EBRD Business Environment and Enterprise Performance Survey (BEEPS). With respect to impartiality, corruption, efficiency, and affordability, assessments of the courts improved marginally, and in the case of affordability fell, between 1999 and 2005. Only with respect to courts' ability to enforce decisions did firms' evaluations improve, but it is not clear that a lack of enforcement was ever a primary barrier to firms' use of legal institutions. Even in the mid-1990s, Hendley (1997, 242 ) found that "rarely do managers cite problems with collection as a reason for bypassing courts" (see also Hendley 2001, 39). Likewise, in a survey conducted in 2000, Yakovlev $(2008,234)$ found that among firms which faced a legal violation but chose not to go to court, fewer than one in eight indicated that enforcement concerns motivated their decision. ${ }^{20}$ Ultimately, what warrants emphasis is the small percentage of firms throughout this period associating positive traits with courts.

Firms' evaluations of other types of formal legal institutions were even more dire than assessments of courts. Yakovlev $(2008,222)$ compared surveys of firms conducted in the same eight regions in 2000 and 2007. Firms' overall assessment of the commercial courts improved slightly. But evaluations of the police, which were already negative in 2000, remained unchanged, while evaluations of local regulators and inspectors fell dramatically.

Beyond state legal capacity, there is little evidence that rising state capacity in a broader sense can account for the evolution of Russian firms' strategies. The Russian economy did grow at a robust annual rate of 7 percent between Putin's rise to power in 2000 and the 2009 financial crisis, in part due to the state's sound macroeconomic policies. But the effect of economic growth and stability on firm strategies was highly ambiguous. Firms' use of legal institutions rose throughout Russia's economic boom - and then rose at an even faster rate as firms turned to the courts to resolve nonpayment conflicts during the 2009 crisis. Not only did use of legal strategies proceed apace across a boom and bust, but firm strategies diverged sharply during the 2009 crisis as compared to firms' reaction to the financial crisis Russia endured in 1998. Between 2008 and 2009, the number of annual interfirm cases spiked by nearly 80 percent. Between 1997 and 1998, annual interfirm cases increased by less than 10 percent, indicating that firms resolved their nonpayment conflicts during this earlier period outside of the formal legal system (VAS 2011). That firms responded differently to similar economic circumstances casts doubt on claims that Putin's macroeconomic policy or economic stability in general can explain firms' increasing reliance on legal strategies.

\footnotetext{
${ }^{20}$ While a new bailiff system created in the late 1990 s aimed to improve enforcement of court decisions, Kahn's (2002) comprehensive analysis of these reforms found them highly ineffective. Among other problems, in the early 2000s bailiffs continued to face over 100 new cases per month, a workload that would have required them to enforce a case every two hours in order to keep pace (Kahn 2002, 159).
} 
FIGURE 1. Russian Firms' Assessment of Courts

Percent of firms agreeing that the following descriptions are associated with the court system.

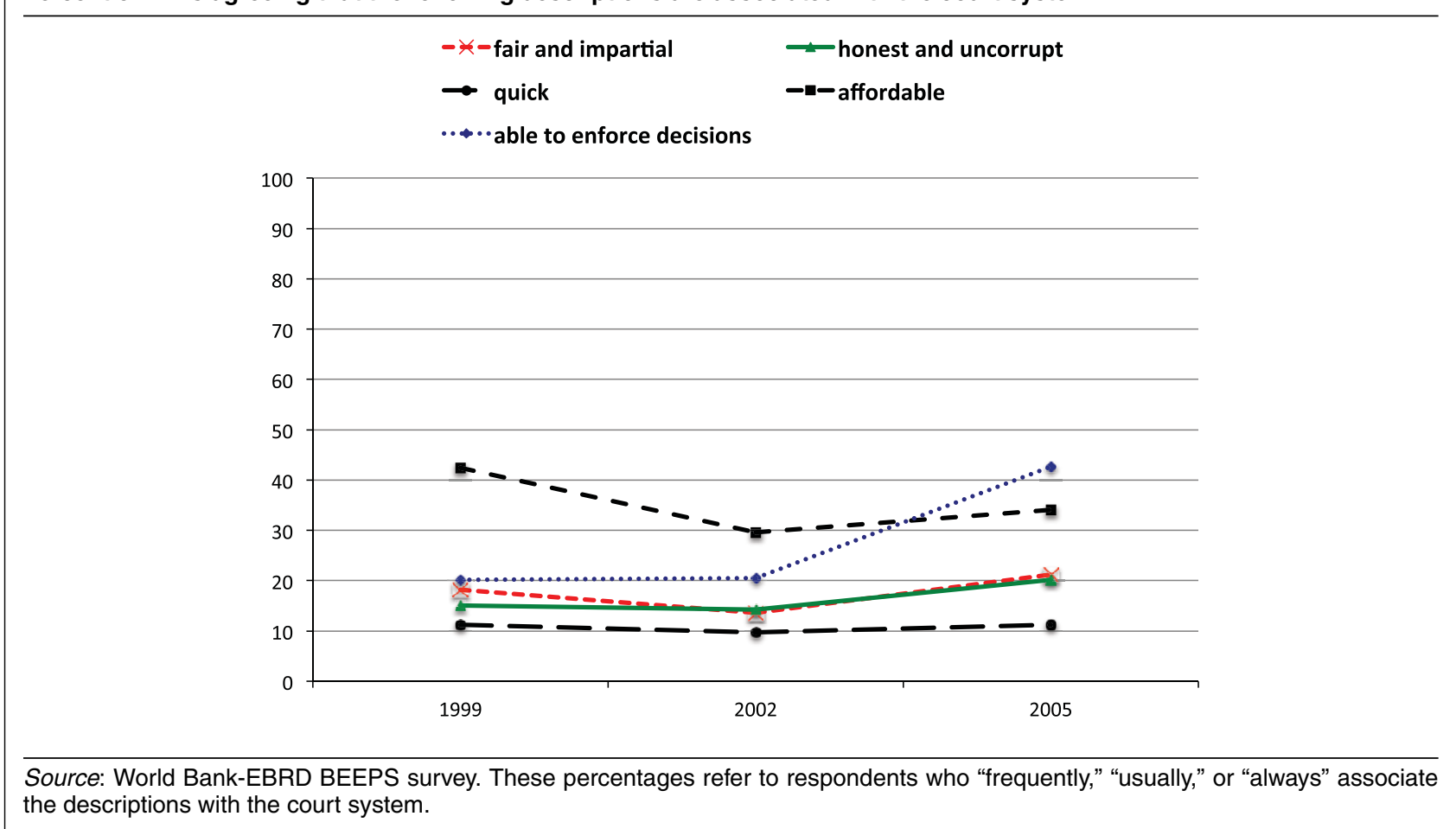

In addition to economic growth, the early years of Putin's regime are often associated with political stability and the reassertion of law and order. While there is some truth to this perspective, it overlooks important trends. As McFaul and Stoner-Weiss (2008, 746) have noted, the frequency of terrorist attacks and the murder rate actually increased during Putin's first two presidential terms. World Bank ratings of Russia's political stability, regulatory quality, and government effectiveness similarly either plateaued or temporarily improved in the early 2000s before again declining. ${ }^{21}$ Moreover, from the vantage point of firms, corrupt state officials' increasing predation soon offset whatever initial stability was provided by Putin's rise to power. By the late 2000s, businesspeople regularly referred to bureaucrats as the primary threat to property security. In the words of a consultant to small businesses in Moscow: "Who cares about criminals? Inspectors can close you in a matter of seconds. This is in itself a kind of mafia system" (Firm 25, interview, 3 June 2009). Corrupt law enforcement officials, meanwhile, threatened entrepreneurs with criminal prosecution in order to force firms to pay bribes or sell assets at below market prices. The most high-profile attack by Russian officials was the 2003 arrest of Mikhail Khodorkovsky, Russia's richest tycoon at the time, but the Khodorkovsky Affair was not an isolated incident, and may have instigated copycat behavior among lower-level

${ }^{21}$ See World Governance Indicators “Country Data Report for Russia" at www.govindicators.org. officials (Gans-Morse 2012). As of 2013, by some estimates approximately 110,000 businesspeople were incarcerated for what in Russia are known as "economic crimes" (Kramer 2013). Indeed, a major puzzle regarding property security strategies in Russia is that firms became increasingly reliant on law not only while the effectiveness of legal institutions remained in doubtbut also while state officials themselves were becoming a fundamental cause of political and economic instability.

In short, although Putin substantially increased funding for legal institutions and expanded government agencies' authority, firms did not perceive a significant improvement in legal institutions' effectiveness. Moreover, by empowering state officials, Putin not only failed to improve the competence of those staffing legal institutions, but also created potent new threats to firms' property rights. Ultimately, while efforts to improve state capacity may have made legal strategies viable, rising institutional effectiveness at best can provide a partial explanation for Russian firms' evolving strategies. A comprehensive explanation requires attention to demand-side factors affecting firms' choices of how to secure property.

\section{Demand-Side Barriers: Exiting the Unofficial Economy}

Proposition 2 of the theory presented above makes clear that firms frequently adopt legal strategies even in the absence of improvements in state legal capacity. 
The proposition furthermore emphasizes factors other than rising legal capacity that can heighten firms' willingness to use law, including the decline of demandside barriers - the practices and beliefs that lead firms to avoid formal institutions. A prominent example of falling demand-side barriers in the Russian case pertains to improved tax compliance, which alleviated firms' concerns that turning to legal institutions could draw attention to illicit tax practices.

Following the Soviet collapse, a large unofficial sector of the economy formed, in part as a result of firms' efforts to avoid taxation. Firms developed numerous schemes to reduce their tax burden, including barter and under-reporting of sales and wages (Shleifer and Treisman 2001, chaps. 5-6). Legal scholars soon recognized tax evasion as a significant demand-side barrier to the use of law. Solomon $(1997,54)$, for instance, noted that "The realities of the tax system and the ways that many firms chose to cope with it (operating partly in the gray economy with two sets of financial records) had the added effect of discouraging those firms from using the courts to resolve disputes." One reason firms avoided courts, he concluded, was because they were "loathe to risk exposing their own illegal practices." Moreover, criminals and corrupt officials sought out firms that violated laws, knowing they could be coerced into using illegal protection services. As a Moscow lawyer explained: "In terms of which businesses face problems with bureaucrats and criminal groups, the most vulnerable are those using 'black cash. ${ }^{22}$ They can't turn to the courts or police for help, and everyone knows that" (Lawyer 8, interview, 6 February 2009).

Russia's 1998 financial crisis provided impetus for firms to exit the informal sector. In particular, a sharp fall in the ruble's value stimulated unexpectedly robust economic growth in the year following the crisis, encouraging firms to formalize their operations in order to take advantage of emerging economic opportunities (Dyufi 2005, 127; Valitova and Tambovtsev 2001, 9). Meanwhile, the crisis instilled a sense of mutual vulnerability among business tycoons and Russia's leaders, who then engaged in a cooperative policymaking effort resulting in tax reforms (Jones Luong and Weinthal 2004)..$^{23}$ These reforms formalized taxpayers' rights and obligations, streamlined tax collection for social funds, and reduced tax rates (Anisimova et al. 2008a; 2008b). Throughout the early 2000s, tax compliance improved significantly, albeit unevenly across different

\footnotetext{
22 The phrase "black cash" (chernye nalichnye) refers to revenues hidden from state authorities.

${ }^{23}$ I make no claim about the crisis's direct impact on firms' property security strategies. Rather, the crisis (and postcrisis recovery) reduced demand-side barriers, which in turn influenced firm strategies. I also do not offer an argument about the crisis's impact across the former Soviet Union. Of the 12 non-Baltic former republics, only four-Russia, Ukraine, Kazakhstan, and Moldovaexperienced negative GDP growth in 1998 (World Development Indicators, accessed 4/2/2016). Moreover, it was the unique features of Russia's crisis - debt default, exchange rate devaluation, postcrisis import-substitution growth - that linked the crisis to firms' exit from the informal economy (see Section 7 of the Online Appendix).
}

types of firms. ${ }^{24}$ According to the World Bank-EBRD BEEPS surveys, the percentage of respondents claiming that typical Russian firms report 90 percent or more of sales revenue for tax purposes rose from 42 percent in 1999 to 65 percent in 2005, a 23 percentage point increase. The change was even greater with respect to the percentage of respondents claiming that typical firms report 100 percent of revenue-a 32 percentage point increase, rising from 28 to 60 percent. ${ }^{25}$

Improved tax compliance had a profound effect on firm strategies. As one respondent explained in reference to addressing employee theft, a widespread concern in Russia, firms "have to operate legally, because when they catch a dishonest accountant in the act of stealing, they explain: Listen fellow, I pay my taxes... so let's go to court. And they will not be afraid to go to court, because they know that their books are clean" (Firm 15, interview, 26 March 2009, emphasis added). A founding partner of a Moscow law firm confirmed these observations, offering a similar logic: "There are [now] more commercial disputes between legal entities. That is, companies have switched, well, are switching, to a legal tax regime system. Accordingly, they turn to law firms, conclude civil contracts, and find protection for their contracts in the courts. Previously, everything was decided with a handshake.... Now it's not like this...." (Lawyer 20, interview, 28 October 2008, emphasis added).

Survey data provide further evidence of the relationship between tax compliance and property security strategies. In an ideal world, panel data would facilitate the tracking of individual firms over time, allowing analysis of how changes in a firm's tax compliance affect its strategies. Panel data measuring the relevant variables do not exist, but it is nonetheless possible cautiously to draw inferences from cross-sectional data. If levels of tax compliance influence strategies, then firms that evade taxes should be less likely to use legal institutions and more likely to rely on violence or corruption. To this end, firms in the survey I conducted were asked "Approximately what percentage of total annual sales would you estimate the typical firm in your line of business reports for tax purposes?" Sixty-eight percent of those responding stated that a typical firm reports more than 90 percent of sales revenues. ${ }^{26}$

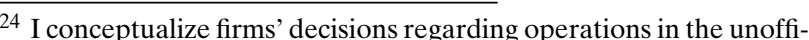
cial economy as a demand-side variable because these are firm-level choices that reflect numerous factors other than state capacity. State policies such as tax reform undeniably influence tax compliance. But even within a given tax and regulatory regime, studies reveal considerable heterogeneity by sector, firm size, ownership type, profitability, growth, and other firm-level variables with respect to paying taxes and formally registering firms (Easter 2012, 105-123; Kanbur and Keen 2015; McPherson and Liedholm 1996).

25 Author's calculations based on data from the BEEPS surveys. Difference-in-means tests show that all differences between the 1999 and 2005 averages are statistically significant at the 99 percent confidence level.

${ }^{26}$ Respondents were given six choices: less than $10 \%, 10$ to $24 \%$, 25 to $49 \%, 50$ to $74 \%, 75$ to $89 \%$, more than $90 \%$, and "not sure/unwilling to answer."
} 


\section{FIGURE 2. Tax Compliance and Propensity to Use Strategies} The figure below shows the difference between the average responses of firms that report less than $90 \%$ of sales revenue for
tax purposes (i.e., "tax violators") and of firms that report more than $90 \%$ (i.e., "tax compliers"), on a 1 to 7 scale where 1 is "very unlikely" and 7 is "very likely," holding other factors constant.

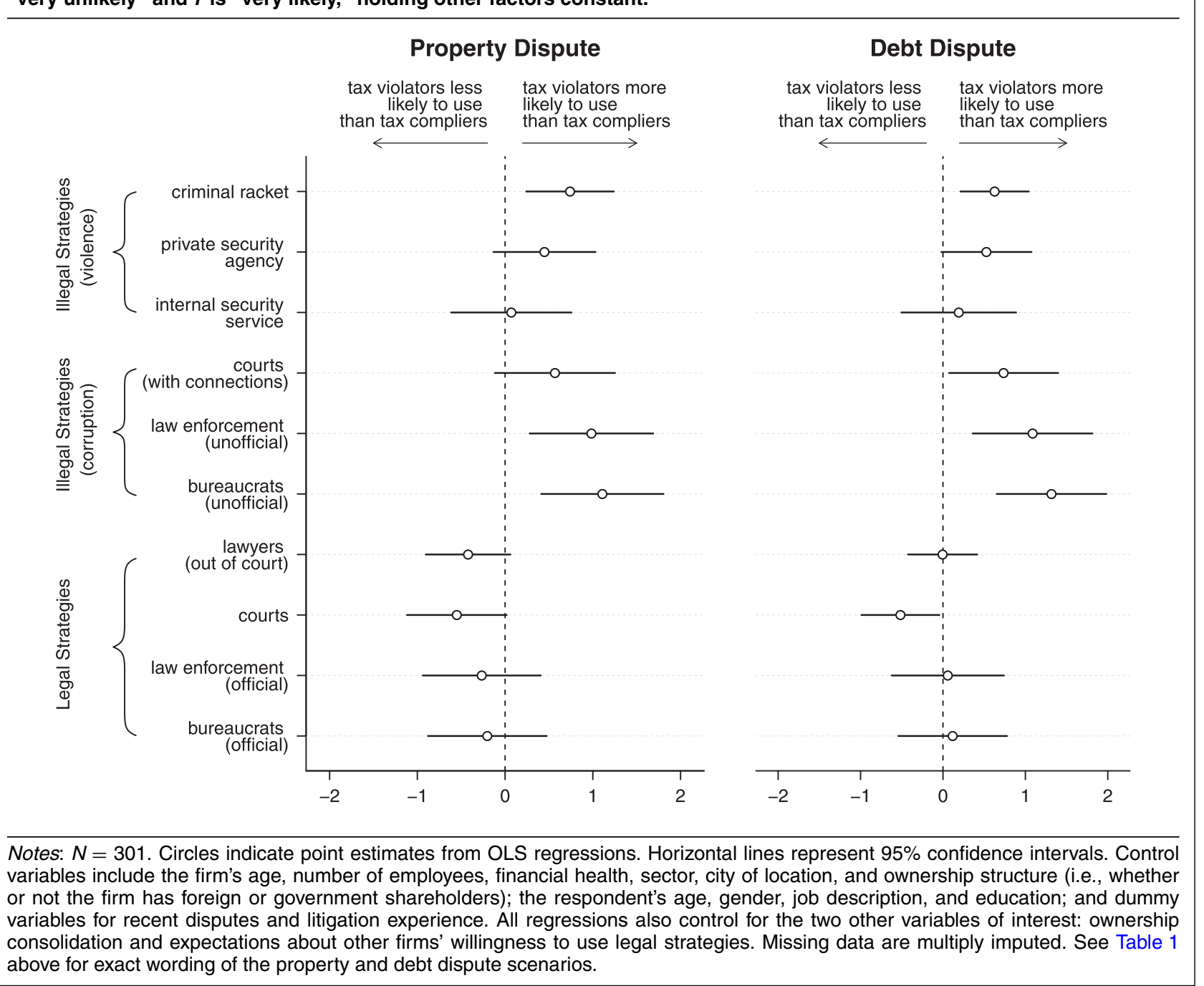

I then reconsidered firms' preferred strategies for responding to the hypothetical property and debt disputes introduced in Table 1 above, in which respondents rated on a 1 to 7 scale their likeliness of using various strategies. The ratings of firms' propensity to use strategies serve as dependent variables for the analyses in Figure 2, which utilize OLS regressions to examine the hypothesis that firms with low levels of tax compliance are less likely to utilize legal and more likely to utilize illegal strategies. ${ }^{27}$ The strategies are arrayed along the vertical axis to the left of Figure 2. The circles represent point estimates of the regression coefficients of a "tax violator" dummy variable that equals one for firms reporting less than 90 percent of

${ }^{27}$ Missing data for all analyses were multiply imputed using the AMELIA II package for R (Honaker et al. 2011), but the results are similar with listwise deletion, as shown in Section 5.5 in the Online Appendix. revenues and zero otherwise. The horizontal lines represent 95 percent confidence intervals. As can be seen in the regression tables in the Appendix, all model specifications control for the wide range of variables listed in the note to Figure 2. Analyses also control for consolidation of ownership in privatized firms and for expectations about other firms' strategies.

Point estimates to the left of the dotted line indicate that firms reporting less than 90 percent of revenue (i.e., "tax violators") rate their likeliness of using a given strategy lower than firms reporting more than 90 percent (i.e., "tax compliers"). Point estimates to the right of the dotted line indicate that "tax violators" are more likely to use a given strategy. In accordance with the hypothesis that tax evading firms are less likely to utilize formal legal institutions, "tax violators" rate their likeliness of turning to courts to address a property dispute around 0.55 points lower $(t=1.91$, $p<0.10)$ than "tax compliers," and their likeliness of 
turning to lawyers to resolve the dispute out of court 0.42 points lower $(t=1.71, p<0.10)$, holding other factors constant. ${ }^{28}$ Tax violators additionally rate their likeliness of using illegal strategies much higher than tax compliers. In the case of turning to law enforcement in an unofficial capacity to help resolve a property dispute, the point estimate is $0.98(t=2.72, p<0.01)$; the point estimate for turning to bureaucrats in an unofficial capacity is $1.10(t=3.10, p<0.01)$. Tax violators also rate their likeliness of resorting to the services of criminal rackets 0.74 points higher $(t=2.93, p<0.01)$. The results pertaining to debt disputes are similar, as shown in Figure 2 and the regression tables in the Appendix. Analyses in Section 5.3 of the Online Appendix show that all results are also robust when using ordered logit regressions in place of OLS. Results additionally are robust when a threshold of 75 percent of sales revenue reported to tax authorities is used to separate "tax violators" and "tax compliers" instead of a 90 percent threshold (see Section 5.4 of the Online Appendix). ${ }^{29}$

To be sure, the results of cross-sectional regressions should be interpreted with caution. Rather than improved tax compliance inducing greater use of legal strategies, it is plausible that heightened effectiveness of legal institutions draws firms out of the unofficial economy. But evidence from surveys probing why firms leave the unofficial economy suggests that endogeneity concerns should not be overstated. For instance, in a survey of Peruvian apparel firms that recently emerged from the informal sector, only six percent of respondents suggested that a motivating factor was to be able to "use the justice system to demand contract execution." The top reasons for reducing activities in the shadow economy were access to more suppliers and customers, the need to obtain credit from formal sources, and the desire to avoid payment of fines (Bruce et al.2007, 46). In the specific case of Russia, moreover, the preceding section demonstrated that there has not been a significant increase in state legal capacity. It follows that it is much more likely that increased tax compliance stimulated firms' greater use of formal legal institutions, rather than the other way around.

In summary, substantial evidence, both from quantitative and qualitative sources of data, indicates that low tax compliance levels create significant demandside barriers to the use of law. Accordingly, as tax compliance in Russia improved, a significant impediment to legal strategies was removed, and firms came to rely increasingly on formal legal institutions.

\footnotetext{
${ }^{28}$ Analyses reveal no relationship, however, between compliance and turning to law enforcement or bureaucrats in an official capacity. Arguably, respondents struggled to imagine relying on these actors in an official capacity, given firms' perceptions, discussed above, that law enforcement agencies are highly corrupt.

${ }^{29}$ Section 5.6 of the Online Appendix shows that results also are robust using an alternative econometric approach that accounts for correlations across firms' willingness to use different types of strategies. The alternative approach first employs k-means cluster analysis to group firms with similar profiles into distinct clusters. Firms' cluster assignments then serve as dependent variables in a set of multinomia logit regressions. Section 5.7 additionally demonstrates that results are robust across firms of different sizes.
}

\section{Effectiveness of Illegal Strategies: The Impact of Ownership Consolidation}

Just as Proposition 2 in the model above emphasizes that falling demand-side barriers can contribute to firms' increased reliance on legal institutions, illegal strategies' declining effectiveness can have a similar effect. In post-Soviet Russia, one factor that significantly contributed to illegal strategies' declining effectiveness pertained to ownership consolidation in privatized firms, which reduced owners' willingness to incur risks associated with violence or corruption. Between 1992 and the end of 1995, Russia privatized over 100,000 small enterprises and nearly 18,000 medium and large firms (Blasi et al. 1997, 189). Due to politics and practicality, the majority of medium and large firms were privatized via a program in which citizens and workers received vouchers exchangeable for shares in privatizing enterprises. Privatization consequently resulted in fractured ownership spread across workers, managers, investment funds, wealthy individuals, and firms with cross-holdings. With minimal minority shareholder protection, limited oversight of managers, and few dominant owners, all parties with control over cash flows or physical assets faced perverse incentives: Transferring resources to front companies or embezzling proceeds from the sale of company assets provided a surer path to enrichment than long-term investment.

The financial crisis of 1998 initiated a significant transformation in ownership structures, dislodging Soviet-era managers and allowing firms which weathered the crisis to acquire failing enterprises' assets (Androsov 2010, 13; Radygin and Arkhipov 2001, 16). Meanwhile, the ruble's depreciation made the manufacturing sector competitive for the first time since communism's collapse, increasing the value of investment in productive assets (Yakovlev et al. 2004, 16).$^{30}$ Following a turbulent period of corporate conflicts, dominant owners appeared. In 1995 less than 15 percent of industrial firms had a shareholder with a majority stake (Dolgopyatova 2005, 7). By the mid-2000s, approximately three-fourths of firms had such a shareholder (Dolgopyatova 2010, 85-6).

Concentration of ownership decreased owners' willingness to risk sanctions that could result from using illegal strategies. With undisputed control of enterprises, owners could reap gains from long-term investments without fear that competing owners or asset-stripping managers would dilute their profits (Yakovlev et al.

\footnotetext{
${ }^{30}$ See Section 7 of the Online Appendix for further details about the links between the 1998 crisis and ownership consolidation. It deserves emphasis that the effects of the crisis on property redistribution were particularly acute in Russia given the pace and form of Russia's privatization. By 1998, Russia's private sector share of GDP reached $70 \%$, the highest among the non-Baltic former Soviet republics. Russia also relied more extensively than its neighbors on voucher privatization, as opposed to cash privatization or manageremployee buyouts, which created unusually severe problems with dispersed ownership (EBRD 1999). Nor did ownership consolidation result from rising state capacity. To the contrary, corporate governance studies emphasize that ownership concentration is indicative of state weakness (Lazareva et al. 2009, 323, 325).
} 
2004, chap. 3). Longer-term investment required stability and predictability, and owners perceived that violence and corruption could undermine both. As Radaev $(2002,44)$ found in his study of the Russian consumer electronics industry in the early 2000s: "Today a definitive reevaluation of risk is occurring among leading players in the market - risk is beginning to be perceived as more painful. The reason is not only possible losses as a consequence of fines and confiscation of goods.... The fact of the matter is that reducing certain types of risks is necessary in order to increase the ... successful promotion of a company's brand." Vladimir Potanin, a prominent Russian tycoon, expressed similar logic in 2003 when he declared:

The "corporate wars" had shown that the damage caused by dubious methods in competition exceeded the potential benefits, even for the "winners"... The positive developments were achieved after most large business groups completed the consolidation of their assets and the owners became interested in improving the quality of management and raising external financing.... Effective Russian companies are interested in having a new business climate in the country, based on civilized rules of business and new ethics of relations (Potanin 2003).

In short, ownership consolidation in privatized firms created incentives for owners to engage in long-term investment rather than rapid acquisition of assets. Under these conditions, illegal strategies' effectiveness declined.

Survey data provide further evidence of the relationships between ownership consolidation and firm strategies. In the survey I conducted, respondents were asked, "Does your firm have a single owner or an owner with a controlling packet of shares?" Of the 301 respondent firms, 78 were privatized firms. Of these, 40approximately 51 percent-report consolidated ownership. As in previous analyses, firms' ratings of their likeliness to use a given strategy to resolve a property or debt dispute serve as the dependent variables in the OLS regression analyses in Figure 3. To assess the effect of consolidated ownership on privatized firms' strategies, I interacted a dummy variable measuring consolidation (with a value of one for consolidated ownership and zero otherwise) with a dummy variable for privatization (one if privatized, zero if the firm was created de novo). The point estimates represented by circles in Figure 3 present the marginal effects of consolidated ownership in privatized firms, calculated as the sum of the coefficients on the consolidation variable and the interaction term.

Figure 3 shows results consistent with the claim that ownership consolidation in privatized firms provides incentives to avoid illegal strategies, even controlling for the wide range of variables listed in the note to Figure 2 as well as for levels of tax compliance and expectations about other firms' strategies. Point estimates to the left of the vertical dotted line indicate that privatized firms with consolidated ownership are less likely to use a given strategy than privatized firms without consolidated ownership. Firms with consoli- dated ownership rate their likeliness of using informal connections in court to resolve a property dispute 1.15 points lower $(t=2.07, p<0.05)$ than those without consolidated ownership, of turning to law enforcement in an unofficial capacity 1.21 points lower $(t=2.29$, $p<0.05$ ), and of turning to bureaucrats in an unofficial capacity 1.02 points lower $(t=2.07, p<0.05)$. They also rate their likeliness of using an internal security service 0.96 points lower. ${ }^{31}$ Once again, analyses using the debt dispute scenario produce similar results, and all results are robust when using ordered logit in place of OLS.

In summary, as owners reoriented toward longerterm investment strategies that require a respectable business reputation and stable business environment, they became less inclined to incur risks entailed in using violence and corruption. Consequently, illegal property security strategies' relative effectiveness declined. Both qualitative and quantitative evidence indicate that this decline contributed to firms' shift away from illegal strategies.

\section{Coordination Dilemmas}

The model introduced above emphasizes that demandside factors not only have a direct effect on firm strategies, but also an indirect effect as firms' expectations about each other's strategies shift. When a substantial number of firms rely on violence and corruption, this hesitancy to use legal institutions may serve as a barrier to other firms' adoption of legal strategies. Such coordination dilemmas were apparent in Russia during the early post-Soviet period. Nevertheless, significant changes in Russian firms' expectations occurred. Moreover, the mechanisms underlying this shift are consistent with the tipping point model developed above. Managers and owners were acutely aware of each other's strategies, and as declines in demandside barriers or illegal strategies' effectiveness induced some firms to adopt legal strategies, this shift provided incentives for others to follow suit.

Russian businesspeople explicitly refer to coordination problems. For example, as a Siberian brick factory owner noted, he would like to operate legally but fears that following the law while others do not means his competitor "has an advantage; he gets ahead more quickly" (Firm 51, interview, 18 September 2009). A small businessman who opened an import business soon after the Soviet Union's collapse described this conundrum in detail:

I am in general an adherent to living by the law, paying taxes, doing business legally.... When [we started] we imported goods, and we tried to pay all taxes.... But as

\footnotetext{
31 The analyses reveal no relationship between consolidation and the use of private security agencies or criminal protection rackets Presumably this is because private security agencies and criminal rackets, as opposed to internal security services, are more frequently employed by smaller firms, whereas privatized firms tend to be large. (The average size of privatized firms in the survey sample is 664 employees compared to a sample average of 390 .)
} 


\section{FIGURE 3. Ownership Consolidation and Propensity to Use Strategies}

The figure below shows the difference between the average responses of privatized firms with consolidated ownership and privatized firms without consolidated ownership, on a 1 to 7 scale where 1 is "very unlikely" and 7 is "very likely," holding other factors constant.

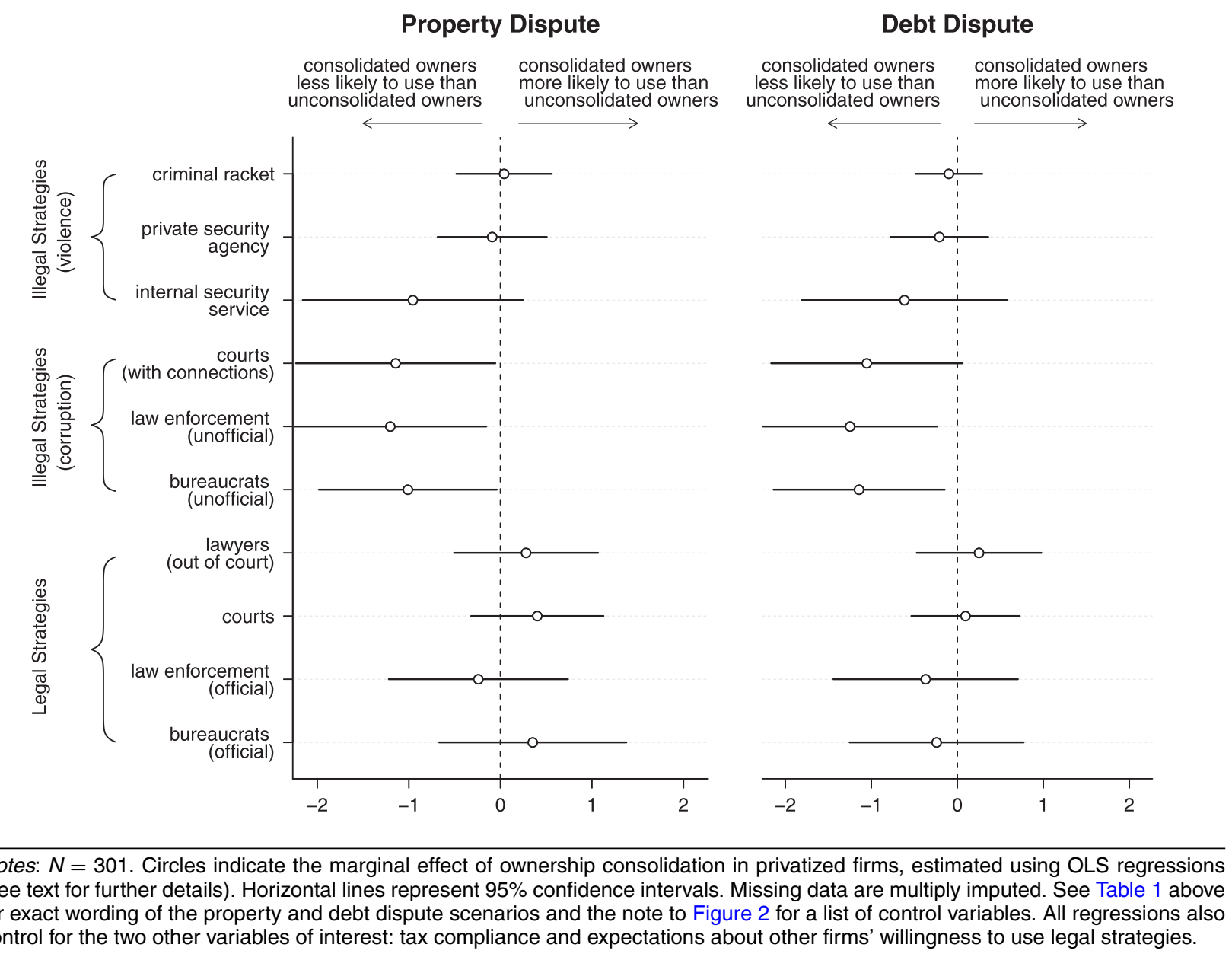

a result, the cost of our goods turned out to be higher than of those goods our competitors were selling on the street .... [This was] because the so-called "black" imports, "grey" imports, shuttle traders and so on were flourishing .... Therefore, in order to survive, we were forced to also switch to these schemes (Firm 21, interview, 3 April 2009).

This downward cost-cutting spiral has significant implications when firms seek to switch from illegal to legal business practices. A manager of a Moscow consumer electronics company interviewed by Radaev $(2002,47)$ in the early 2000s captured this logic perfectly, explaining "It's not possible to legalize one's business by oneself. It's necessary that the rest of the market, and maybe even the whole market, is legalized. Because if 90 percent work legally, and 10 percent illegally, then we can't do anything. Everyone [i.e., consumers] will eventually run to the 10 percent." Beyond costcutting, businesspeople note that illegal strategies' use elicits responses in kind, creating a vicious cycle. An expatriate with experience in the Russian steel industry recalled the blunt assessment of his firm's general director regarding the use of violence: "We don't send in guys with guns because we don't want guys with guns coming to see us" (Firm 10, interview, 14 March 2009). Radaev's (2002, 50) study of the consumer electronics sector again came to similar conclusions, finding that "Any rough use of force [by one firm against another] signifies the beginning of a "war." "

Survey data once more provide the opportunity to examine relationships between coordination problems and property security strategies. In the 2010 survey I conducted, respondents were asked about the extent to which they agreed with the statement: "The majority of firms with whom I conduct business do their best to follow the law." Sixty-six percent of respondents agreed with the statement; 34 percent did not. ${ }^{32}$ As

\footnotetext{
32 Agreement refers to respondents who stated they "strongly agree" or "agree" with the statement.
} 


\section{FIGURE 4. Coordination Problems and Propensity to Use Strategies}

The figure below shows the difference between the average responses of firms which disagree that the majority of other firms are law-abiding (i.e., "pessimists") compared to those which agree (i.e., "optimists"), on a 1 to 7 scale where 1 is "very unlikely" to use a given strategy and 7 is "very likely," holding other factors constant.
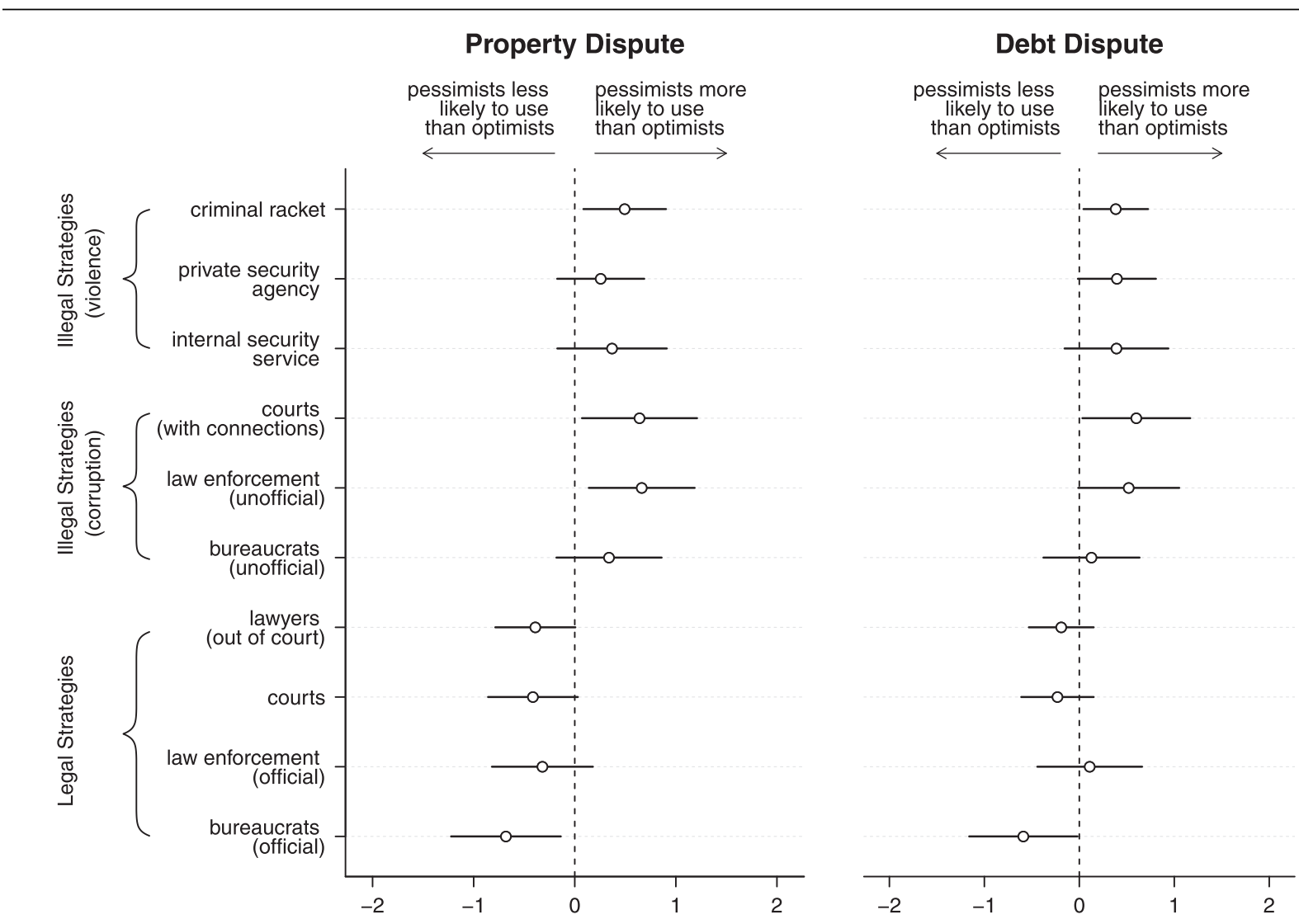

Notes: $N=301$. Circles indicate point estimates from OLS regressions. Horizontal lines represent $95 \%$ confidence intervals. Missing data are multiply imputed. See Table 1 above for exact wording of the property and debt dispute scenarios and the note to Figure 2 for a list of control variables. All regressions also control for the two other variables of interest: tax compliance and ownership consolidation.

above, firms' ratings of their propensity to use distinct strategies serve as the dependent variables for the OLS regression analyses in Figure 4. Strategies are arrayed along the vertical axis to the left of the figure. Circles represent point estimates of the coefficient on a dummy variable that equals one if respondents disagree with the statement that the majority of other firms are lawabiding and zero otherwise. The horizontal lines represent 95 percent confidence intervals.

Point estimates to the left of the vertical dotted line indicate that respondents perceiving the majority of firms with whom they do business to be lawbreakers (i.e., "pessimists") are less likely to use a given strategy than those perceiving the majority of their business partners to be law-abiding (i.e., "optimists"). Point estimates to the right of the line indicate the opposite. Controlling for the variables listed in the note to Figure 2 as well as for tax compliance and ownership consolidation, "pessimists" on average rate their likeliness of using courts to address a property dispute about 0.42 points lower $(t=1.85, p<0.10)$ than "optimists," and rate their likeliness of turning to lawyers out of court about 0.39 points lower $(t=1.95$, $p<0.10)$. Similarly, "pessimists" rate their likeliness of turning to bureaucrats in an official capacity 0.68 points lower $(t=2.45, p<0.05)$. "Pessimist" firms that perceive others to be lawbreakers also display a greater propensity to use illegal strategies. Their average ratings for using informal connections in court are 0.64 points higher $(t=2.21, p<0.05)$. Similarly, they rate their likeliness of turning to law enforcement in an unofficial capacity 0.67 points $(t=2.50, p<0.05)$ and of seeking the services of a criminal protection racket 0.49 points higher $(t=2.37, p<0.05)$. Results related to debt disputes suggest a similar pattern and are again robust when using ordered logit in place of OLS.

As in previous sections, the results of cross-sectional analyses should be interpreted cautiously. Firms overestimating others' lawfulness may also overestimate their own use of legal strategies, which could produce spurious correlations. Yet while such concerns deserve 
attention, the fact that both quantitative and qualitative data point to similar conclusions supports the contention that coordination problems significantly affect firms' strategies.

Further evidence of the role of coordination problems emerges from analysis of how firms' expectations shifted over time. Whereas 66 percent of respondents in the 2010 survey I conducted agreed with the statement "The majority of firms with whom I conduct business do their best to follow the law," only 31 percent of respondents agreed that "Ten years ago, the majority of firms with whom I conducted business did their best to follow the law." How did such a shift in expectations occur? Evidence from in-depth interviews as well as sectoral studies conducted by Russian researchers is consistent with the tipping point interpretation of evolving firm strategies: As some firms adopted legal strategies in response to a decline in demand-side barriers or illegal strategies' effectiveness, other firms recognized peers' changing practices and reevaluated their own strategies.

The case of the small business owner of a longrunning import operation discussed above provides an illustrative example of how corruption's relative costs affect firm strategies. As noted, this owner fell prey to competitive pressures in the 1990s to adopt illicit practices. But over time the rising costs of bribery decreased illegal strategies' effectiveness and altered his willingness to rely on corruption: “... the costs of these 'gray' [i.e., semilegal] schemes grew, maybe not so much that it became economically profitable, but at least that it was not so harmful to work legally. When such an opportunity arose, we... switched a large part [of our business] to legal schemes" (Firm 21, interview, 3 April 2009). Meanwhile, Radaev's (2002) study of the Russian consumer electronics sector, also cited above, provides evidence of how initial shifts in strategies gain momentum. As discussed, consumer electronic firms expressed unwillingness to legalize operations unless a large segment of their sector abandoned illicit practices simultaneously. When Radaev probed further to understand how a widespread shift was occurring despite such barriers, he found that once the process of legalization was underway, firms were acutely aware of changing tendencies and consistently reconsidered their strategies in response: "Directors [of firms] know each other, they have followed the activities of their 'neighbors' for many years and, accordingly, they have a good conception of what to expect from them, and what is better to not count on" (Radaev 2002, 48).

In summary, firms' expectations about each other's willingness to use law independently affect the likeliness that firms will adopt legal strategies. These coordination problems can lead to vicious cycles that lock economies in unlawful equilibria. But when a decline in demand-side barriers or illegal strategies' effectiveness leads a vanguard of firms to abandon illegal strategies, the potential arises for a shift from vicious to virtuous cycles, in which positive expectations encourage further reliance on formal legal institutions.

\section{DISCUSSION}

This article has offered a theory of institutional demand that provides insights into the conditions under which firms utilize formal legal institutions. The theory proposes that state legal capacity is a necessary but insufficient condition for firms to turn to law. Rather, firms frequently adopt legal strategies in response to falling demand-side barriers or declining effectiveness of illegal strategies, the influence of which is amplified by the effects of firms' expectations about each other's willingness to use law.

This article's aim is theory building, with the case of Russia serving to illustrate the theory's key tenets. But the theory of institutional demand developed here offers insights into property security strategies in a broad range of countries with intermediate levels of state legal capacity - that is, in countries where (1) a modicum of state legal capacity exists yet (2) formal legal institutions are not sufficiently effective to ensure a unique equilibrium in which all firms use legal strategies. In other words, scope conditions encompass all countries other than failed states and the subset of OECD countries in which the vast majority of firms already shun strategies involving violence or corruption. Moreover, although the specific types of demand-side barriers in intermediate-capacity states may vary from country to country, the theory suggests that these barriers will largely fall into the categories of firms' operations in the unofficial economy, collective action problems, or cultural norms. Likewise, the factors influencing illegal strategies' effectiveness may be context-specific, but these factors are likely to relate to transaction costs or the risk of sanctions.

To be sure, firms' reliance on legal institutions should not be equated with the emergence of the rule of law, a system in which laws equally constrain all actors, both state and private. But a focus on firms' property security strategies forces scholars to recognize understudied challenges that firms' use of violence or corruption pose for rule-of-law development. A focus on firm strategies also forces rule-of-law advocates to look beyond formal legal institutions with the aim of alleviating demandside barriers. These lessons hold relevance for much of the developing world.

Turning attention from rulers to firms additionally encourages new perspectives on state building. As Migdal (2001) notes, advocating what he refers to as a "state-in-society" approach, state-building's success depends on societal actors' strategies. State building is not only a top-down process of implementing institutional blueprints, but also a bottom-up process involving the daily role of numerous "ordinary" actors in "the ongoing struggles among shifting coalitions over the rules for daily behavior" (Migdal 2001, 10). Strategies utilizing violence or corruption-not only on the part of firms but also on the part of political parties, citizens, or lower-level bureaucrats -intrinsically undermine or subvert formal institutions. By undermining state institutions, such strategies contribute to a fundamental divergence between on-the-ground practices and formal rules. Even more nefariously, by subverting state 
institutions, illegal strategies imbue state policies with the logic of private gain rather than public interest. By contrast, legal strategies reinforce formal institutions, as citizens' and firms' reliance on formal institutions infuses these institutions with authority.

Ultimately, by utilizing state institutions, societal actors contribute on a micro-level to state building; by circumventing or subverting state institutions, they contribute to institutional breakdown. Consequently, the implications of the demand-side approach to prop- erty security advocated here are wide-ranging. Removing demand-side barriers to the use of formal institutions or mitigating illegal alternatives' effectiveness may be essential not only for developing the rule of law, but also for improving state capacity more broadly.

\section{SUPPLEMENTARY MATERIALS}

To view supplementary material for this article, please visit https://doi.org/10.1017/S0003055416000691 
APPENDIX

TABLE A1. Regression Results-Property Dispute Scenario

\begin{tabular}{|c|c|c|c|c|c|c|c|c|c|c|}
\hline & Lawyers & $\begin{array}{l}\text { Courts } \\
\text { (formal) }\end{array}$ & $\begin{array}{c}\text { Law } \\
\text { Enf. } \\
\text { (formal) }\end{array}$ & $\begin{array}{c}\text { Gov. } \\
\text { Officials } \\
\text { (formal) }\end{array}$ & $\begin{array}{l}\text { Courts } \\
\text { (informal) }\end{array}$ & $\begin{array}{l}\text { Law } \\
\text { Enf. } \\
\text { (informal) }\end{array}$ & $\begin{array}{c}\text { Gov. } \\
\text { Officials } \\
\text { (informal) }\end{array}$ & $\begin{array}{l}\text { Criminal } \\
\text { Rackets }\end{array}$ & $\begin{array}{l}\text { Private } \\
\text { Sec. } \\
\text { Agency }\end{array}$ & $\begin{array}{l}\text { Internal } \\
\text { Security }\end{array}$ \\
\hline (1) Tax violator & $\begin{array}{r}-0.42 \dagger \\
(0.25)\end{array}$ & $\begin{array}{r}-0.55 \dagger \\
(0.29)\end{array}$ & $\begin{array}{r}-0.27 \\
(0.34)\end{array}$ & $\begin{array}{r}-0.20 \\
(0.34)\end{array}$ & $\begin{array}{c}0.57 \\
(0.35)\end{array}$ & $\begin{array}{l}0.98^{* *} \\
(0.36)\end{array}$ & $\begin{array}{l}1.10^{* *} \\
(0.36)\end{array}$ & $\begin{array}{l}0.74^{* *} \\
(0.25)\end{array}$ & $\begin{array}{c}0.45 \\
(0.29)\end{array}$ & $\begin{array}{l}0.07 \\
(0.35)\end{array}$ \\
\hline $\begin{array}{l}\text { (3) Privatized* } \\
\text { consolidated }\end{array}$ & 0.29 & 0.42 & -0.26 & 0.34 & $-1.15^{*}$ & $-1.21^{*}$ & $-1.02^{*}$ & 0.05 & -0.06 & -0.95 \\
\hline (marginal effects) & $(0.40)$ & $(0.37)$ & $(0.50)$ & $(0.52)$ & $(0.55)$ & $(0.53)$ & $(0.49)$ & $(0.26)$ & $(0.30)$ & $(0.62)$ \\
\hline (5) Others unlawful & $\begin{array}{r}-0.39 \dagger \\
(0.20)\end{array}$ & $\begin{array}{r}-0.42 \dagger \\
(0.23)\end{array}$ & $\begin{array}{r}-0.31 \\
(0.26)\end{array}$ & $\begin{array}{r}-0.68^{*} \\
(0.28)\end{array}$ & $\begin{array}{l}0.64^{*} \\
(0.29)\end{array}$ & $\begin{array}{r}0.67^{*} \\
(0.27)\end{array}$ & $\begin{array}{c}0.34 \\
(0.26)\end{array}$ & $\begin{array}{r}0.49^{*} \\
(0.21)\end{array}$ & $\begin{array}{c}0.25 \\
(0.22)\end{array}$ & $\begin{array}{c}0.37 \\
(0.28)\end{array}$ \\
\hline Privatized & $\begin{array}{r}-0.29 \\
(0.40)\end{array}$ & $\begin{array}{r}-0.21 \\
(0.42)\end{array}$ & $\begin{array}{r}-1.13^{*} \\
(0.52)\end{array}$ & $\begin{array}{r}-0.25 \\
(0.54)\end{array}$ & $\begin{array}{c}0.41 \\
(0.57)\end{array}$ & $\begin{array}{r}-0.28 \\
(0.59)\end{array}$ & $\begin{array}{c}0.08 \\
(0.56)\end{array}$ & $\begin{array}{r}-0.48 \\
(0.36)\end{array}$ & $\begin{array}{r}-0.94^{*} \\
(0.38)\end{array}$ & $\begin{array}{c}0.51 \\
(0.59)\end{array}$ \\
\hline Consolidated & $\begin{array}{c}0.34 \\
(0.31)\end{array}$ & $\begin{array}{c}0.12 \\
(0.34)\end{array}$ & $\begin{array}{r}-0.55 \\
(0.37)\end{array}$ & $\begin{array}{c}0.07 \\
(0.40)\end{array}$ & $\begin{array}{l}0.06 \\
(0.42)\end{array}$ & $\begin{array}{r}-0.77 \dagger \\
(0.42)\end{array}$ & $\begin{array}{r}-0.44 \\
(0.42)\end{array}$ & $\begin{array}{c}0.09 \\
(0.27)\end{array}$ & $\begin{array}{r}-0.20 \\
(0.32)\end{array}$ & $\begin{array}{r}-0.18 \\
(0.38)\end{array}$ \\
\hline $\begin{array}{l}\text { Privatized* } \\
\text { consolidated }\end{array}$ & -0.05 & 0.30 & 0.29 & 0.27 & $-1.20 \dagger$ & -0.44 & -0.58 & -0.04 & 0.14 & -0.77 \\
\hline & $(0.47)$ & $(0.48)$ & $(0.62)$ & $(0.63)$ & $(0.68)$ & $(0.66)$ & $(0.63)$ & $(0.35)$ & $(0.41)$ & $(0.71)$ \\
\hline Firm age & $\begin{array}{c}0.10 \\
(0.08)\end{array}$ & $\begin{array}{l}0.24^{*} \\
(0.10)\end{array}$ & $\begin{array}{l}0.12 \\
(0.10)\end{array}$ & $\begin{array}{c}0.12 \\
(0.11)\end{array}$ & $\begin{array}{l}0.00 \\
(0.13)\end{array}$ & $\begin{array}{c}0.07 \\
(0.12)\end{array}$ & $\begin{array}{r}-0.06 \\
(0.12)\end{array}$ & $\begin{array}{c}0.06 \\
(0.08)\end{array}$ & $\begin{array}{c}0.11 \\
(0.09)\end{array}$ & $\begin{array}{c}0.04 \\
(0.12)\end{array}$ \\
\hline Foreign owned & $\begin{array}{c}0.17 \\
(0.27)\end{array}$ & $\begin{array}{c}0.76^{*} \\
(0.31)\end{array}$ & $\begin{array}{r}-0.26 \\
(0.40)\end{array}$ & $\begin{array}{c}-0.60 \\
(0.44)\end{array}$ & $\begin{array}{c}0.33 \\
(0.43)\end{array}$ & $\begin{array}{c}0.12 \\
(0.43)\end{array}$ & $\begin{array}{c}-0.01 \\
(0.43)\end{array}$ & $\begin{array}{c}0.50 \\
(0.34)\end{array}$ & $\begin{array}{c}0.34 \\
(0.41)\end{array}$ & $\begin{array}{c}0.20 \\
(0.44)\end{array}$ \\
\hline Gov. owned & $\begin{array}{l}0.05 \\
(0.33)\end{array}$ & $\begin{array}{c}0.36 \\
(0.35)\end{array}$ & $\begin{array}{c}0.00 \\
(0.39)\end{array}$ & $\begin{array}{c}0.31 \\
(0.44)\end{array}$ & $\begin{array}{r}-0.09 \\
(0.46)\end{array}$ & $\begin{array}{r}-0.71 \\
(0.45)\end{array}$ & $\begin{array}{r}-0.44 \\
(0.49)\end{array}$ & $\begin{array}{c}0.05 \\
(0.33)\end{array}$ & $\begin{array}{r}-0.07 \\
(0.36)\end{array}$ & $\begin{array}{r}-0.27 \\
(0.51)\end{array}$ \\
\hline Bus. assoc. & $\begin{array}{l}0.14 \\
(0.21)\end{array}$ & $\begin{array}{r}-0.02 \\
(0.22)\end{array}$ & $\begin{array}{l}0.71^{* *} \\
(0.25)\end{array}$ & $\begin{array}{c}0.89^{* *} \\
(0.27)\end{array}$ & $\begin{array}{c}0.62^{*} \\
(0.31)\end{array}$ & $\begin{array}{c}0.31 \\
(0.26)\end{array}$ & $\begin{array}{c}0.34 \\
(0.28)\end{array}$ & $\begin{array}{c}0.07 \\
(0.24)\end{array}$ & $\begin{array}{c}0.05 \\
(0.24)\end{array}$ & $\begin{array}{l}0.60 \dagger \\
(0.31)\end{array}$ \\
\hline Rights violated & $\begin{array}{c}0.01 \\
(0.22)\end{array}$ & $\begin{array}{c}0.30 \\
(0.28)\end{array}$ & $\begin{array}{c}0.27 \\
(0.29)\end{array}$ & $\begin{array}{l}0.29 \\
(0.31)\end{array}$ & $\begin{array}{c}0.34 \\
(0.32)\end{array}$ & $\begin{array}{r}0.57 \dagger \\
(0.33)\end{array}$ & $\begin{array}{c}0.39 \\
(0.31)\end{array}$ & $\begin{array}{c}0.18 \\
(0.22)\end{array}$ & $\begin{array}{c}0.22 \\
(0.27)\end{array}$ & $\begin{array}{c}0.37 \\
(0.32)\end{array}$ \\
\hline Litigated & $\begin{array}{l}0.45 \\
(0.28)\end{array}$ & $\begin{array}{c}0.28 \\
(0.30)\end{array}$ & $\begin{array}{r}0.64^{*} \\
(0.31)\end{array}$ & $\begin{array}{r}-0.27 \\
(0.32)\end{array}$ & $\begin{array}{c}0.21 \\
(0.35)\end{array}$ & $\begin{array}{c}0.02 \\
(0.33)\end{array}$ & $\begin{array}{r}-0.17 \\
(0.33)\end{array}$ & $\begin{array}{c}-0.28 \\
(0.22)\end{array}$ & $\begin{array}{r}-0.44 \dagger \\
(0.25)\end{array}$ & $\begin{array}{r}-0.07 \\
(0.36)\end{array}$ \\
\hline Legal ed. & $\begin{array}{r}-0.16 \\
(0.27)\end{array}$ & $\begin{array}{c}0.26 \\
(0.32)\end{array}$ & $\begin{array}{c}0.21 \\
(0.39)\end{array}$ & $\begin{array}{c}0.42 \\
(0.39)\end{array}$ & $\begin{array}{l}0.19 \\
(0.44)\end{array}$ & $\begin{array}{c}0.26 \\
(0.38)\end{array}$ & $\begin{array}{r}0.75 \dagger \\
(0.41)\end{array}$ & $\begin{array}{r}0.65^{*} \\
(0.31)\end{array}$ & $\begin{array}{c}0.19 \\
(0.29)\end{array}$ & $\begin{array}{c}0.39 \\
(0.38)\end{array}$ \\
\hline Age & $\begin{array}{c}0.00 \\
(0.01)\end{array}$ & $\begin{array}{l}0.03^{*} \\
(0.01)\end{array}$ & $\begin{array}{r}-0.02 \dagger \\
(0.01)\end{array}$ & $\begin{array}{r}-0.02 \dagger \\
(0.01)\end{array}$ & $\begin{array}{c}0.01 \\
(0.02)\end{array}$ & $\begin{array}{c}-0.01 \\
(0.01)\end{array}$ & $\begin{array}{c}0.00 \\
(0.01)\end{array}$ & $\begin{array}{c}-0.03^{* * *} \\
(0.01)\end{array}$ & $\begin{array}{r}-0.02 \dagger \\
(0.01)\end{array}$ & $\begin{array}{r}-0.01 \\
(0.01)\end{array}$ \\
\hline $\begin{array}{l}\text { Male } \\
\text { (Intercept) }\end{array}$ & $\begin{array}{c}0.28 \\
(0.20) \\
5.57^{* * *} \\
(1.00)\end{array}$ & $\begin{array}{c}0.24 \\
(0.23) \\
3.21^{* *} \\
(1.10)\end{array}$ & $\begin{array}{c}0.09 \\
(0.26) \\
8.03^{* * *} \\
(1.11)\end{array}$ & $\begin{array}{c}0.01 \\
(0.26) \\
6.84^{* * *} \\
(1.22)\end{array}$ & $\begin{array}{c}0.43 \\
(0.30) \\
1.04 \\
(1.28)\end{array}$ & $\begin{array}{c}0.08 \\
(0.28) \\
3.29^{* *} \\
(1.25)\end{array}$ & $\begin{array}{c}0.28 \\
(0.28) \\
2.86^{*} \\
(1.22)\end{array}$ & $\begin{array}{c}-0.24 \\
(0.21) \\
3.42^{* * *} \\
(0.80)\end{array}$ & $\begin{array}{c}0.26 \\
(0.24) \\
3.77^{* * *} \\
(1.05)\end{array}$ & $\begin{array}{c}-0.10 \\
(0.29) \\
4.32^{* * *} \\
(1.19)\end{array}$ \\
\hline City dummies & yes & yes & yes & yes & yes & yes & yes & yes & yes & yes \\
\hline Sector dummies & yes & yes & yes & yes & yes & yes & yes & yes & yes & yes \\
\hline Firm size dummies & yes & yes & yes & yes & yes & yes & yes & yes & yes & yes \\
\hline $\begin{array}{l}\text { Firm finances } \\
\text { dummies }\end{array}$ & yes & yes & yes & yes & yes & yes & yes & yes & yes & yes \\
\hline Job title dummies & yes & yes & yes & yes & yes & yes & yes & yes & yes & yes \\
\hline$N$ & 301 & 301 & 301 & 301 & 301 & 301 & 301 & 301 & 301 & 301 \\
\hline$R$ sq. & 0.25 & 0.30 & 0.26 & 0.27 & 0.27 & 0.32 & 0.31 & 0.36 & 0.30 & 0.30 \\
\hline Adj. $R$ sq. & 0.14 & 0.19 & 0.15 & 0.16 & 0.16 & 0.21 & 0.20 & 0.27 & 0.19 & 0.19 \\
\hline
\end{tabular}


TABLE A2. Regression Results—Debt Dispute Scenario

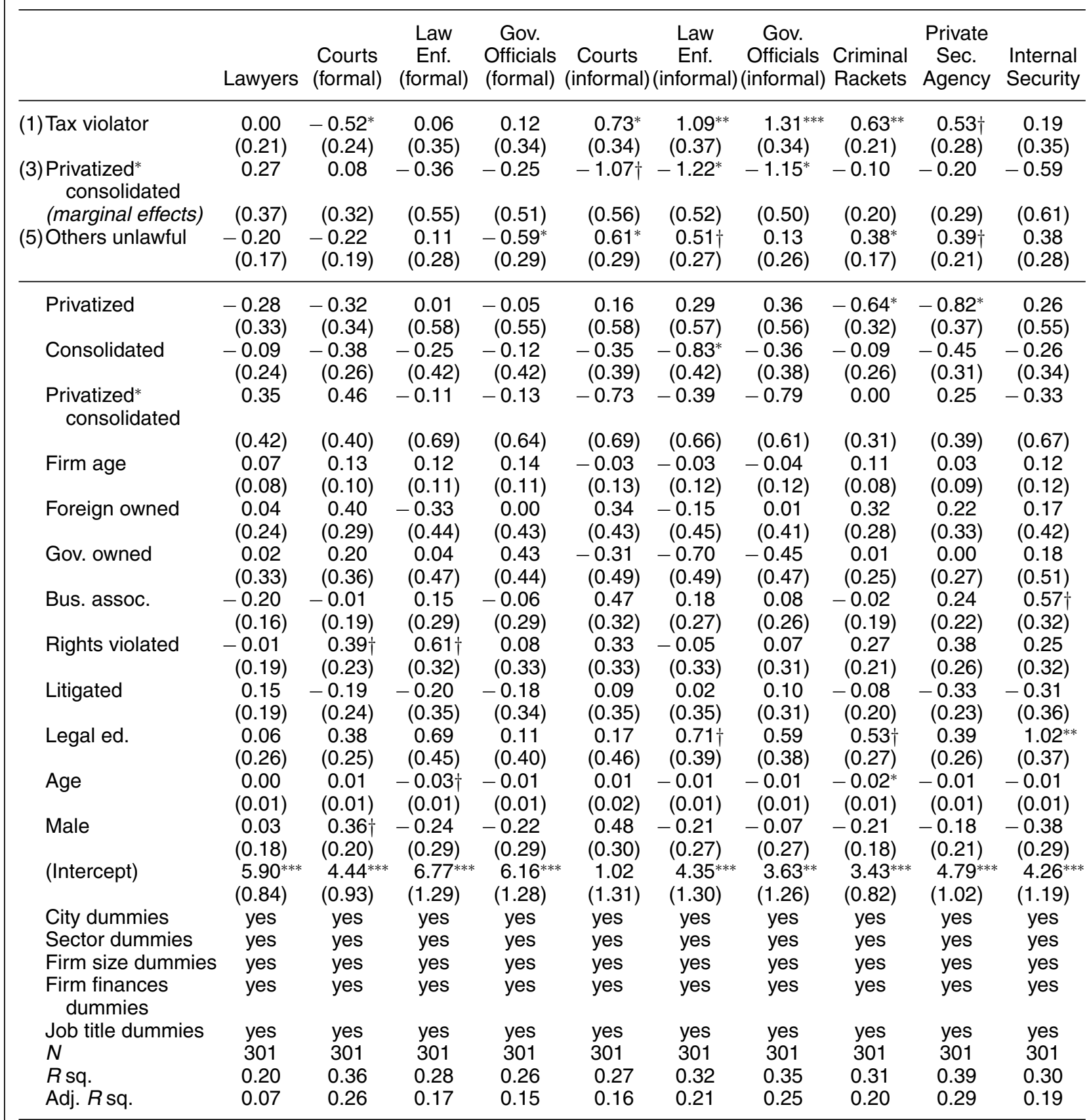

Notes: Row (1) shows the OLS regression coefficients displayed in Figure 2. Row (3) shows the marginal effects displayed in Figure 3 , which are the sum of the coefficients for the consolidation dummy and consolidation*privatization interaction variables. Row (5) shows the coefficients displayed in Figure 4.

${ }^{\dagger}$ Significant at $p<0.10 ;{ }^{*} p<0.05 ;{ }^{* *} p<0.01 ;{ }^{* *} p<0.001$. Robust standard errors in parentheses.

\section{REFERENCES}

Acemoglu, Daron, and James A. Robinson. 2006. "Economic Backwardness in Political Perspective." American Political Science Review 100 (1): 115-31.

Androsov, Ivan V. 2010. “Osobennosti Transformatsii Otnoshenii Sobstvennosti v Usloviyakh Krisisnykh Etapov Tsiklichnosti Razvitiya Rynochnoy Ekonomiki [Transforming Property Relations under Crisis Conditions of the Cyclical Stages of Market Economy Development]." Vestnik TGU 3 (83): 9-17.
Anisimova, Lyudmila, Pavel Kadochnikov, Tatiana A. Malinina, Vladimir Nazarov, Sergei Germanovich Sinelnikov-Murylev, and Ilya Trunin. 2008a. Reforma Nalogoblazheniya Dokhodov Naseleniya $v$ Rossii [Reform of the Personal Income Taxation in Russia]. Moscow, Russia: Gaidar Institute for Economic Policy.

Anisimova, Lyudmila, Tatiana A. Malinina, and Elena V Shkrebela. (2008b). Nalog na Pribyl Organizatisii [The Corporate Income Tax]. xpn. Moscow, Russia: Gaidar Institute for Economic Policy. Arrow, Kenneth J. 1962. "The Economic Implications of Learning by Doing." The Review of Economic Studies 29 (3): 155-73. 
Barnes, Andrew. 2003. "Russia's New Business Groups and State Power." Post-Soviet Affairs 19 (2): 154-86.

Barzel, Yoram. 1997. Economic Analysis of Property Rights. New York: Cambridge University Press.

Blasi, Joseph R., Maya Kroumova, and Douglas Kruse. 1997. Kremlin Capitalism: Privatizing the Russian Economy. Ithaca, NY: Cornell University Press.

Bruce, John W., Omar Garcia-Bolivar, Michael Roth, Anna Knox, and Jon Schmid. 2007. Land and Business Formalization for Legal Empowerment of the Poor. Strategic Overview Paper, USAID. Ithaca, NY.

de Soto, Hernando. 2003. The Mystery of Capital: Why Capitalism Triumphs in the West and Fails Everywhere Else. New York, NY: Basic Books.

Dolgopyatova, Tatiana. 2005. Evolution of Corporate Control Models in Russian Companies: New Trends and Factors. Higher School of Economics Working Paper.

Dolgopyatova, Tatiana. 2010. "Kontsentratsiya Sobstvennosti v Rossiiskoi Promyshlennosti: Evolyutsionnye Izmeneniya na Mikrourovne [Concentration of Ownership in Russian Industry: Evolutionary Change on the Micro-level]." Dzhurnal Novoi Ekonomicheskoi Assotsiatsii (8): 80-100.

Dyufi, Karolina. 2005. "Barter i Sdelki Mezhdu Kompaniyami: K Normalizatsii Raschetov Posle Krizisa 1998 [Barter and Interenterprise Transactions: Toward the Normalization of Accounts after the 1998 Crisis]." Problemy Prognozirovaniya (1): 121-30.

Easter, Gerald M. 2012. Capital, Coercion, and Postcommunist States. Ithaca, NY: Cornell University Press.

European Bank for Reconstruction and Development (EBRD). 1999. Transition Report 1999: Ten Years of Transition.

Frye, Timothy. 2004. "Credible Commitment and Property Rights: Evidence from Russia." American Political Science Review 98 (3): $453-66$.

Frye, Timothy. 2010. "Corruption and the Rule of Law." In Russia after the Global Economic Crisis, eds. Anders Åslund, Sergei Guriev, and Andrew Kuchins, eds. Washington, DC: Peter G. Peterson Institute for International Economics, 79-94.

Frye, Timothy, and Ekaterina Zhuravskaya. 2000. "Rackets, Regulation, and the Rule of Law." Journal of Law, Economics, and Organization 16 (2): 478-502.

Gans-Morse, Jordan. 2012. "Threats to Property Rights in Russia: From Private Coercion to State Aggression." Post-Soviet Affairs 28 (3): 263-95.

Ginsburg, Tom, and Glenn Hoetker. 2006. "The Unreluctant Litigant? An Empirical Analysis of Japan's Turn to Litigation.” The Journal of Legal Studies 35 (1): 31-59.

Greif, Avner. 1993. "Contract Enforceability and Economic Institutions in Early Trade: The Maghribi Traders' Coalition." The American Economic Review 83 (3): 525-48.

Haber, Stephen, Armando Razo, and Noel Maurer. 2003. The Politics of Property Rights: Political Instability, Credible Commitments, and Economic Growth in Mexico, 1876-1929. New York: Cambridge University Press.

Hay, Jonathan R., and Andrei Shleifer. 1998. "Private Enforcement of Public Laws: A Theory of Legal Reform." The American Economic Review 88 (2): 398-403.

Hendley, Kathryn. 1997. "Legal Development in Post-Soviet Russia." Post-Soviet Affairs 13 (3): 228-51.

Hendley, Kathryn. 1999. "Rewriting the Rules of the Game in Russia: The Neglected Issue of Demand for Law." East European Constitutional Review 8 (4): 89-95.

Hendley, Kathryn. 2001. "Beyond the Tip of the Iceberg: Business Disputes in Russia." In Assessing the Value of Law in Transition Economies, ed. Peter Murrell. Ann Arbor, MI: University of Michigan Press, pp. 20-55.

Hendley, Kathryn. 2006. "Assessing the Rule of Law in Russia." Cardozo Journal of International and Comparative Law 14 (2): 347-91.

Hendley, Kathryn, Peter Murrell, and Randi Ryterman. 2000. "Law, Relationships and Private Enforcement: Transactional Strategies of Russian Enterprises." Europe-Asia Studies 52 (4): 627-56.

Hill, Fiona, and Clifford G. Gaddy. 2013. Mr. Putin: Operative in the Kremlin. Washington, DC: Brookings Institution Press.
Hoff, Karla, and Joseph E. Stiglitz. 2004. "After the Big Bang? Obstacles to the Emergence of the Rule of Law in Post-Communist Societies." American Economic Review 94 (3): 753-63.

Hoffman, David E. 2002. The Oligarchs: Wealth and Power in the New Russia. New York, NY: Public Affairs.

Hoffman, David. 1997. Banditry Threatens the New Russia. The Washington Post (May 12). https://www.washingtonpost.com/ archive/politics/1997/05/12/banditry-threatens-the-new-russia/ e46ef158-bd84-4ca9-870f-612817fe5854/

Honaker, James, Gary King, and Matthew Blackwell. 2011. "Amelia II: A Program for Missing Data." Journal of Statistical Software 45 (7): $1-47$.

Johnson, Simon, John McMillan, and Christopher Woodruff. 2002. "Property Rights and Finance." American Economic Review 92 (5): 1335-56.

Jones Luong, Pauline, and Erika Weinthal. 2004. "Contra Coercion: Russian Tax Reform, Exogenous Shocks, and Negotiated Institutional Change." American Political Science Review 98 (1): 139-52.

Kahn, Peter L. 2002. "The Russian Bailiffs Service and the Enforcement of Civil Judgments." Post-Soviet Affairs 18 (2): 148-81.

Kanbur, Ravi, and Michael Keen. 2015. "Reducing Informality." Finance \& Development 52 (1): 52-4.

Khodorych, Aleksei. 2002. "Poslednii Dovod Zashchity [The Defense's Last Argument]." Dengi (April 17).

Kramer, Andrew E. 2013. "Russia's Stimulus Plan: Open the Gulag Gates." New York Times (August 8).

Kuran, Timur. 1989. "Sparks and Prairie Fires: A Theory of Unanticipated Political Revolution." Public Choice 61 (1): 41-74.

Laitin, David D. 1998. Identity in Formation: The Russian-Speaking Populations in the Near Abroad. Ithaca, NY: Cornell University Press.

Lazareva, Olga, Andrei Rachinsky, and Sergey Stepanov. 2009. “A Survey of Corporate Governance in Russia." In Corporate Governance in Transition Economies, ed. Robert W. McGee. New York, NY: Springer, 315-49.

Macaulay, Stewart. 1963. "Non-Contractual Relations in Business: A Preliminary Study." American Sociological Review 28: 55-67.

Markus, Stanislav. 2012. "Secure Property as a Bottom-Up Process: Firms, Stakeholders, and Predators in Weak States." World Politics 64 (2): 242-77.

Matveeva, N. 2007. "Kriminologicheskiy analiz sostoyaniya zashchishchennosti predprinimatelei ot tyazhkogo nasiliya v Tsentralnom Federalnom okruge [Criminological analysis of the entrepreneurs' degree of protection from harmful violence in the Central Federal District]." In Kriminalnaya ekonimika i organizovannaya prestupnost [The criminal economy and organized crime], ed. A. Dolgova. Moscow: The Russian Criminological Association and the Nizhgovorod Academy of the MVD.

McFaul, Michael, and Kathryn Stoner-Weiss. 2008. "The Myth of the Authoritarian Model: How Putin's Crackdown Holds Russia Back." Foreign Affairs 87 (1): 68-84.

McMillan, John, and Christopher Woodruff. 1999. "Dispute Prevention without Courts in Vietnam." Journal of Law, Economics, \& Organization 15 (3): 637-58.

McPherson, Michael A., and Carl Liedholm. 1996. "Determinants of Small and Micro Enterprise Registration: Results from Surveys in Niger and Swaziland." World Development 24 (3): 481-7.

Migdal, Joel S. 2001. State in Society: Studying how States and Societies Transform and Constitute One Another. New York: Cambridge University Press.

Milhaupt, Curtis J., and Mark D. West. 2000. “The Dark Side of Private Ordering: An Institutional and Empirical Analysis of Organized Crime." The University of Chicago Law Review 67 (1): 41-98.

Mnookin, Robert H., and Lewis Kornhauser. 1978. "Bargaining in the Shadow of the Law: The Case of Divorce." Yale Law Journal 88 (5): 950-97.

North, Douglass C. 1981. Structure and Change in Economic History. New York, NY: Norton.

Olson, Mancur. 1993. "Dictatorship, Democracy, and Development." American Political Science Review 87 (3): 567-76.

Pistor, Katharina. 1996. "Supply and Demand for Contract Enforcement in Russia: Courts, Arbitration, and Private Enforcement." Review of Central and East European Law 22 (1): 55-87. 
Pistor, Katharina, Philip Wellons, and Jeffrey Sachs. 1999. The Role of Law and Legal Institutions in Asian Economic Development: 1960-1995. Oxford: Oxford University Press.

Polishchuk, Leonid, and Alexi Savvateev. 2004. "Spontaneous (Non) Emergence of Property Rights." The Economics of Transition 12 (1): 103-27.

Posner, Richard A. 2000. "Is the Ninth Circuit too Large? A Statistical Study of Judicial Quality.” The Journal of Legal Studies 29 (2): 711-9.

Potanin, Vladimir. 2003. "Corporate Governance: "Russian Model" in Progress." Journal on Foreign Affairs and International Relations. Available at http://eng.globalaffairs.ru/number/n_1724

Radaev, Vadim. 1999. "The Role of Violence in Russian Business Relations." Problems of Economic Transition 41 (12): 34-61.

Radaev, Vadim. 2002. Institutsionalnaya Dinamika Rynkov i Formirovanie Novych Konseptsii Kontrolya [Institutional Market Dynamics and the Formation of New Concepts of Control]. Higher School of Economics working paper.

Radygin, Alexander, and Sergei Arkhipov. 2001. Tendentsii v Structure Sobstvennosti, Intensivnost Korporativnykh Konfliktov i Finansovoe Sostoyanie Predpriyatii [Trends in Ownership Structure, the Intensity of Corporate Conflicts, and the Financial Condition of Enterprises]. Russian-European Centre for Economic Policy report.

Sborov, Afanasiy. 2003. Oborotni v pogonakh [Werewolves in Epaulets]. Vlast (July 21).

Schelling, Thomas C. 1971. "Dynamic Models of Segregation." The Journal of Mathematical Sociology 1 (2): 143-86.

Shleifer, Andrei, and Daniel Treisman. 2001. Without a Map: Political Tactics and Economic Reform in Russia. Cambridge, MA: MIT Press.

Shvets, Julia. 2012. "Judicial Institutions and Firms' External Finance: Evidence from Russia." Journal of Law, Economics, \& Organization 29 (4): 735-64.

Solomon, Peter H. 1997. "The Persistence of Judicial Reform in Contemporary Russia." East European Constitutional Review 6: $50-6$.

Sonin, Konstantin. 2003. "Why the Rich may Favor Poor Protection of Property Rights.” Journal of Comparative Economics 31 (4): 715-31.

Spector, Regine. 2008. "Securing Property in Contemporary Kyrgyzstan." Post-Soviet Affairs 24 (2): 149-76.
Taylor, Brian D. 2011. State Building in Putin's Russia: Policing and Coercion After Communism. New York: Cambridge University Press.

Valitova, Lilia, and Vitaly Tambovtsev. 2001. "Rossiiskii Barter v 1992-2000 Godakh [Russian Barter during 1992-2000s]." Russian Economic Barometer (1): 8-12.

Volkov, Vadim. 2002. Violent Entrepreneurs: The Use of Force in the making of Russian Capitalism. Ithaca, NY: Cornell University Press.

Vysshyi Arbitrazhnyi Sud (VAS). 2011. Osnovnye Pokazateli Raboty Arbitrazhniykh Sudov RF [Basic Indicators of the Work of the the Commercial Courts of the RF]. Vysshyi arbitrazhnyi sud [Supreme Arbitrazh Court] in Moscow.

Wank, David. 2004. "Business-State Clientelism in China: Decline or Evolution." In Social Connections in China: Institutions, Culture, and the Changing Nature of Guanxi, eds. Thomas Gold, Doug Guthrie and David Wank. New York: Cambridge University Press, 97-116.

Whiting, Susan H. 2010. "Contracting and Dispute Resolution among Chinese Firms: Law and Its Substitutes." In Dynamics of Local Governance in China During the Reform Era, eds. Tse-Kang Leng and Yun-Han Chu. Lanham, MD: Lexington Books, pp. 181-224.

Williamson, Oliver E. 1985. The Economic Institutions of Capitalism. New York, NY: Macmillan.

Wilson, Ian. 2010. "Reconfiguring Rackets: Racket Regimes, Protection and the State in Post-New Order Jakarta." In The State and Illegality in Indonesia, eds. Edward Aspinall and Gerry van Klinken. Lanham, MD: Lexington Books, 239-60.

Winters, Jeffrey A. 2011. Oligarchy. New York: Cambridge University Press.

Yakovlev, Andrei. 2008. Pravo i Pravoprimenenie v Rossii Glazami Biznesa: Chto Izmenilos za Sem Let [Law and Law Enforcement in Russia through the Eyes of Business: What Changed in the Last Seven Years]. In Pravoprimenenie: Teoriya i Praktika, ed. Yury Tikhomirov. Moscow: Formula Prava, 21439.

Yakovlev, Andrei, Victoria Golovanova, Tatiana G. Dolgopyatova, Boris Kuznetsov, and Yuri Simachev. 2004. Spros na Pravo $v$ Sfere Korporativnogo Upravleniva [Demand for Law in the Sphere of Corporate Governance]. Moscow: Higher School of Economics. 